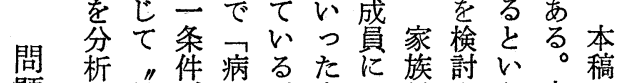

今当題守最架人充わ家よ族っのる貝する家は 日た起こ生た族れ内て発、。家 試保染さ活わ条補病とわ直族 み健注“机をれ件完に心れ面員 ら・有をて検は、さよういる れ医效維お討、第代つ方れて罪 て療な持らし (1) 替て法注い病 い社方しずた役にさ、で、るが る会法て、結割親れ当つこ保も 幾学古第果構族よ該病う健た う研学主造・う家人し医ら か究る。条その近と族家た療す の流病件れ変隣市㵀課問家 研

究い

は实そ 考病にぞ容のる従題題族 家おれ援吕前にには集 る家い一機助、のア 対、団 現の

代 端

家 緒

族 に

のつ

保 以

さ障に健 れ害基 ・ よの害看 う実い護 態て機 解難態 明病明 $L 队 5$

交加

う通に

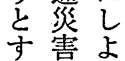
る 等 る \&に のよす

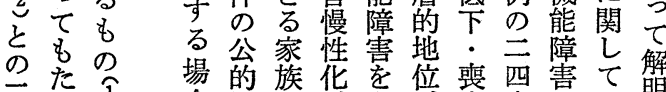
の低、変更の割口て療の 内. $、$ 三化に過構 1 役社影 内階一なは程造于割会響 奉屓二し。公で変た梏の学索 必小事 (2) 福第容た造高病

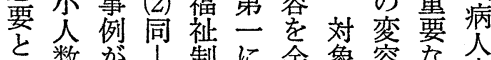

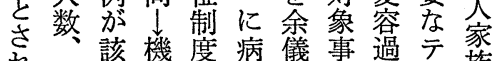
ろ早当能と病儀事過テ程门族

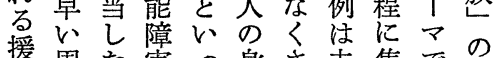
助周た害っ身さ期焦で生

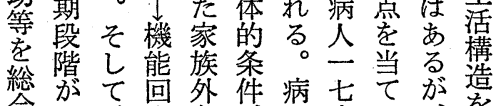
合認覆条件病七て事て文 的 (3) 件第 が例、そ分

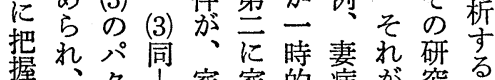
握多】家家的病加究る 第1機族族に人家方㐬 う齐熋にのせ七族法に 々条を障機階よ事の論卡 手件と害能層低例機によ 場的族华者位变四害て盟

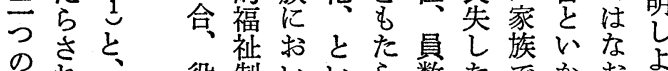

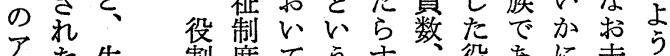
ア゚た生割度てうす往あに米う 吕家活構には造よ㤎生割る関開試 1族構造ようおの否活遂。連拓み チ生論変ておおパを期は、染た に活的容かむ夕規段野も 大機視: 過乃孙定階他るでの 別能点程う第ンしとの市あで

小笹

田谷

利 春

勝 美 


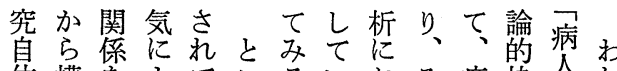

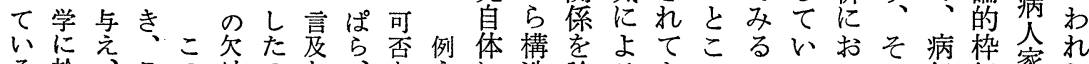
る於このけのして交えに造論るきろこるいの気組家わ そてパのよてがて病は拉川じ家たでと生て成との族机

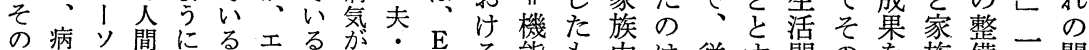

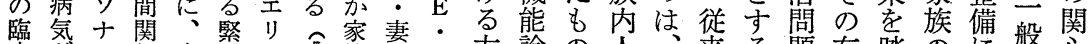

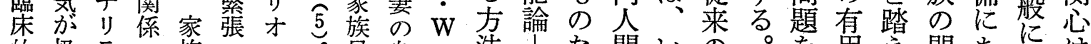

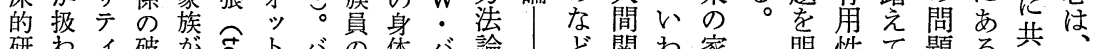

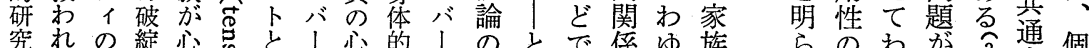

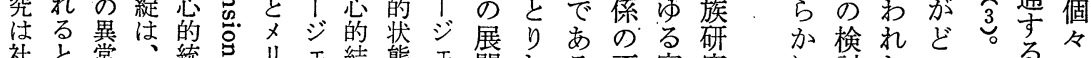

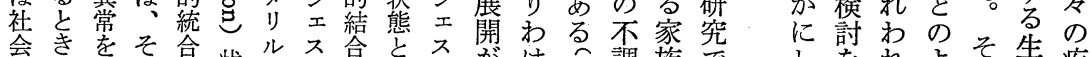

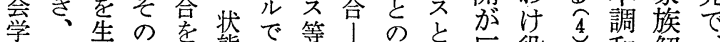
よそ变襄態市等

り机原返軸とる。相々連立映割こを体病 むは因しとしが互りに Sさ理こ問論気 し主文亡把、作わっ・和論れ題に衣 ろとさしる把々用けいコてのら挍

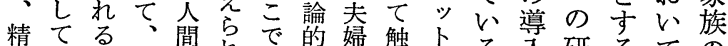

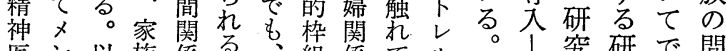
医ン以族係る、組係てル 学夕後員衣 6 家老に心は にル合しす族解与る

於・ ア心て。解体えが結

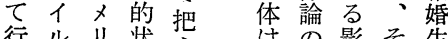

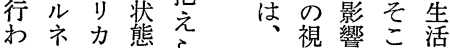

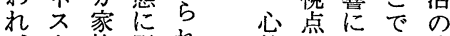
を族影れ的でつは成 役さ。社響る統展いも功 割し会老と合開てっの

究研で問 は究あ題 へ、やる。少 认的病そな う相気れか 互空 ら 家作貧はず 族用困唁 研論の病及
しをれるそ生疾 試のうこ活病 必み研にで閴の 要る究把大䞨種 ととの握本と類 さと視さ稿そ傆 るも点れでて原 援に方きまをを 助つ法たず明相 内病を它家違 容人提を族かに に家示簡社にも つ族し単会し加 、会、に学うか てが実ふにるわ 触直証り打方方 れ面分返い法ず

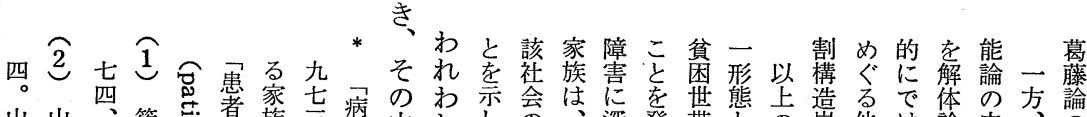

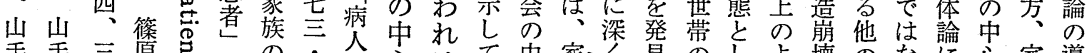

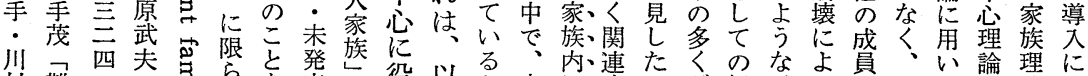

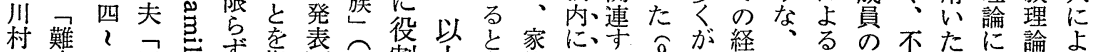

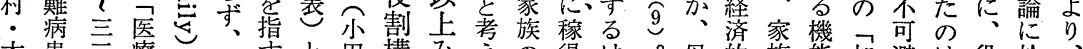

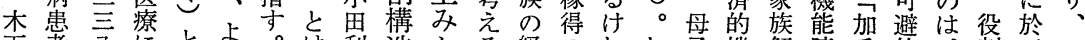

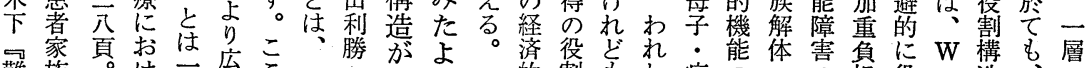

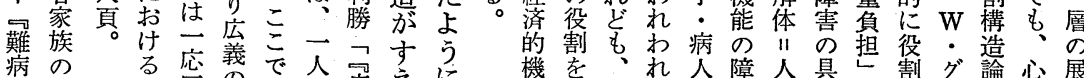

患諸家品概いあ病えに 奢閴族別念うる人概う家れ家

之題参学京病は族る族

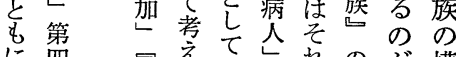

に四氙云用々热のが構

七琵兄衣以役妥造 重回垈るるは厹割当と 紀早本も。医病配で機

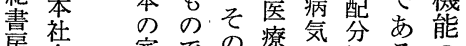

房会 家での療気分るる

一学繁离意従家関と関

旮会培。味事旗䒚考連

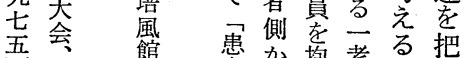

副九 - 萣占热察光

副九应たい二 と

機を:れ人障人具乵割グ論心展 能十イは・害間体の老、が的開

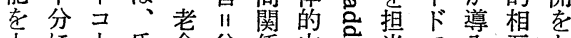
十に 分担ルの等困不容。であさ作け に当と言、の調は怘きつれ用て 維しはうそ問和明さ哭たた、論い 持う考ごの題論きすい新のる

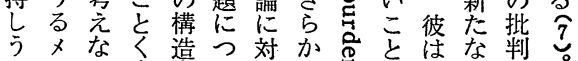
るンい家卡いしに怘、、展と こバ。族 何て 触しに開開し ががま成か搔清心触会見登 不いり上のて秀なれそいら場 可な上の欠い氏いてのうれし

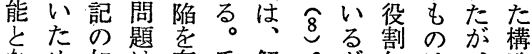
なめ如は有氏解。方尔は損意々 こ当の能る役買れ機 
科のる あ茄信

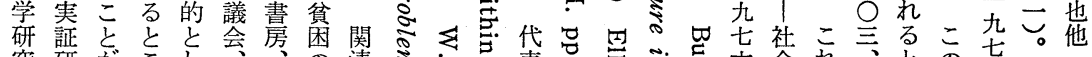

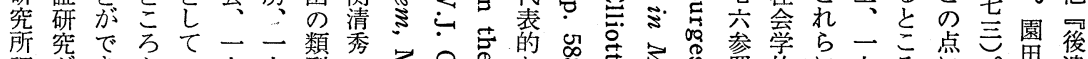

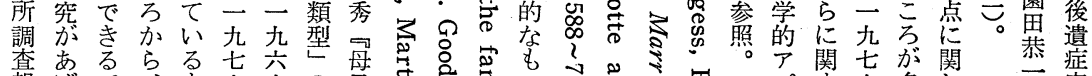

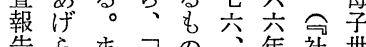
告らま病の、年社世 第れた病で三心会带 7 集。方家はす。同学 一青法族心こ悲論究 九市代に関就政二北 六に視関対音党十海 年打点す象研族号道 等る異数族望福厹生 被る劣の直福九部 保落客接政五一 讙江容証病策罗九 研英究気家空同吾 究等 一何族福都年 東のつら関全市同 京都と市連国家家 学兗て関解会族族 社困举係明福藅

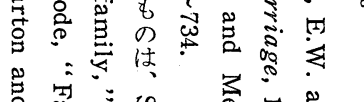

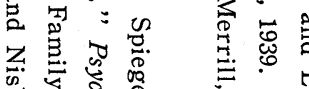

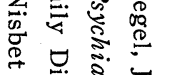

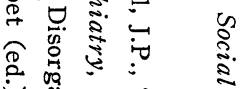

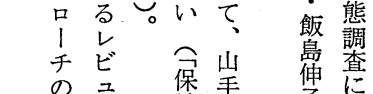
会層げ方を祉誠壊

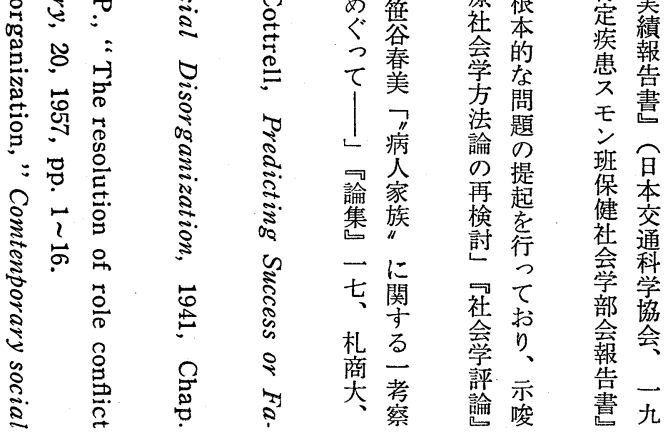

るる過ざのとな井造よ保関済割を

必な第程る減とがら和でっ家障連的以保家 要ら一にを退こ期な夫㐫て族機さ機上障族

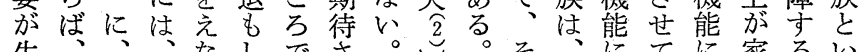

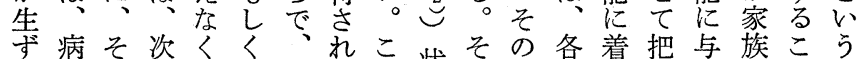
る。れのなは成るの桨れ機構自握光員卡社

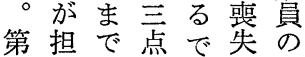
三っ通をあを発 にてり仮 る 病 病た家的う。ち説ら 人役族にこしか は割機提鬲々れ れ 従は能示時そぞ のの家るつ結れ 役成族こ病果ま 割員内と人役で 義にでが家割有 務よ維で族構し がつ持よ造て 免てすうのは、 除補つ。役必た さ完ゔ割然役 れ・け構的割 る代よ造に遂 と替方変行 同学栾容能 時態は熊成守しる劣会 個維言を維員るるう打傷あ撃病る団

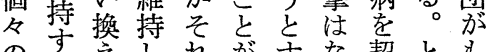
のす完しれ加尔な契とも 成るれてぞ必る機こつ 員たばいれ要時大㢳基 にめの集。地思は流てで本 そ家団こ位わ专充 の族とうにれそのる日能 役員しし态るれがのにの 割相てたじ。ゆあをおひ

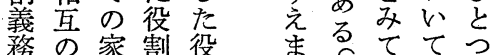

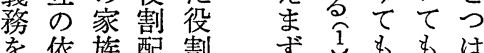
孝存族配割守过安生

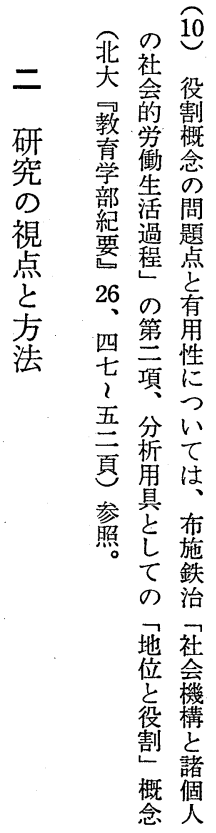




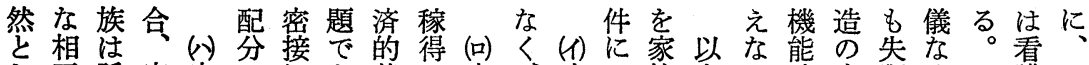

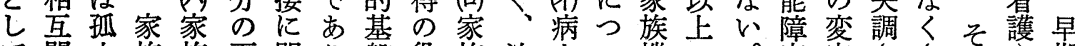
て関立族族再関り盤役族治人い機の。害容ささのや期 弱係乙外外調連、䒜割内療のて能諸兄せ結介回

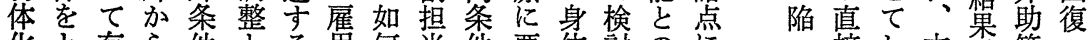
化と存ら件とる用何当件要体討のにっ接し本果等

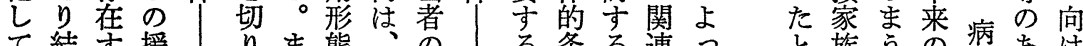

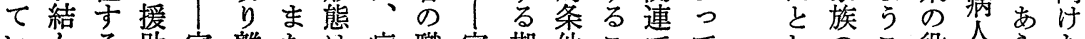
、んる助家離たは病職家期件こでてしのこ役合た

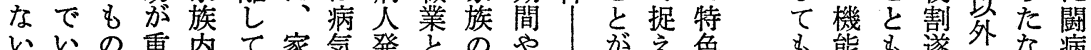

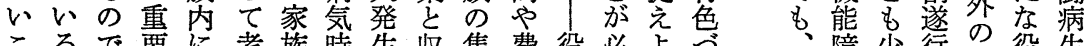
こるで要に考族時生收集費役必占心障少行家役生 と。はな機え構のに入团角割要うり一害なに家割活 加親な役能る成医よ括的を遂でをら定くも旗名に

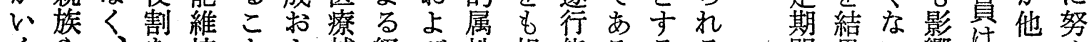

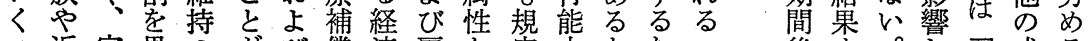

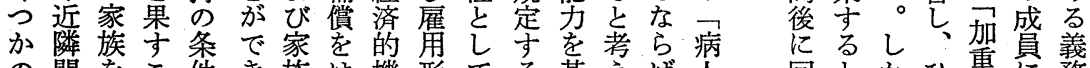
の関をこ件き族は機形てる基えば人回名ひ重に務 研係ととがな生じ能態の問本る家復はしい賏っ肪 究はりに充、活めの階題的。少族守限なて掍け付

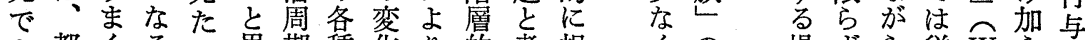

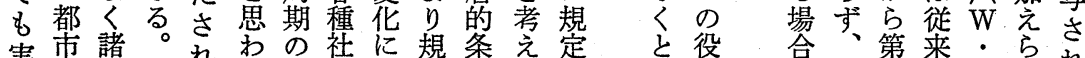

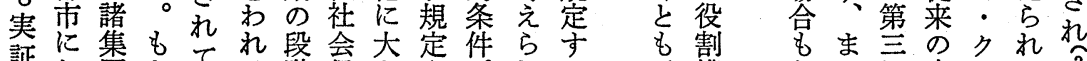

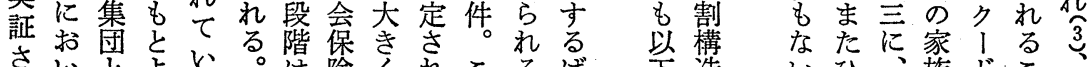

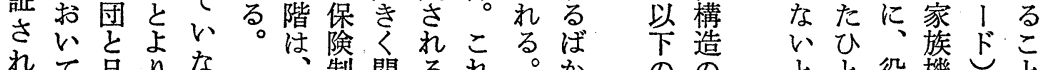

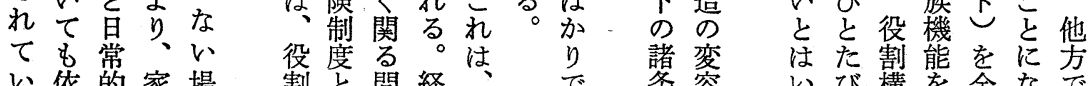
小依的家場割灾問経、で案容いび構を余なで

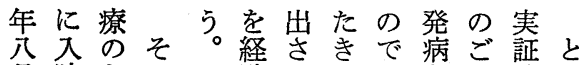

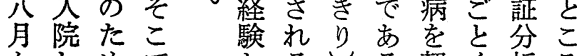

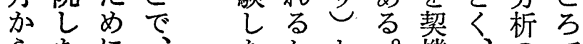
らたにたかと。機、ので $\overrightarrow{0} こ$ 内札 病がにことて対

○科幌人一よの病象わ 月の外市本っっ場る人をれ に专来内人のて合家家どわ かる通の打术管族のれ け患院 A 上イ病施の边势 て者中病びン病設役へうこ 調との院そト人療割のにの 查气患の をの者医 行家棉療 族 相 た卷当談 象疾 亡患協 ᄂ てよを 潠過克 乙去 昭之性 和の疾 五病患 ○院 治
のに芜欽構方選研 家な族造れ定究 族るの天的孝を 等炎浣変机る進 対思得容のかめ 象方割と堂了方 とれ梅在動プとに する造笔態只あ る。療的 15 た

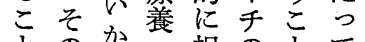
衣加捉 がたな通方方で苦 必める院よ法あ虑 要に差もうはっし さ望点字家。点

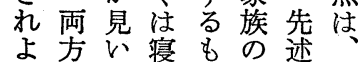

て公的更児䦕でて機こ焉

え福、が護つかしで

ら祉こでのいるての

れ諸うき手て観いわ

る制しよ伝み点るれ

度たう六焦でわ

が、。、みあれ

家わ療たららの

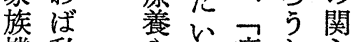

機私管病吕心

能的含々家々住

維; 後れ家之

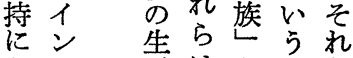

とフ 活は炎占

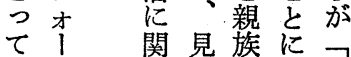

看 守舞向病

過儿る近讨人

でな相金粼台家

き援談銭。れ族

な助等的職

関 $の$ 援場心の

家係側助集了援

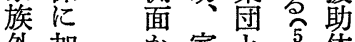

多加架家占集

件元捉? 社本它 と、妄会稿乞 
病望棓な多院多質

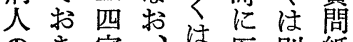

のき家、配医別紙

年た族本配療の考

龄々に稿偶相時角

は関で者談間い

第等用で䇪湾た

代表るいるに别面

か々のデに場調

ら第でا次掦查

六 3 西名行では

代表る。注て行実

帒。病は施病

に病息れさ人

わ命全時た蒙

り、対二で面㵀

象七面は病加

四家撸職人同

○性族聴境本席

代格、聚晹し

が素た実にた

八病灰施場

人命施尔合

簡蒙たはも

最管家主族

多触族家它る

\begin{tabular}{|c|c|c|c|c|c|}
\hline & 男 & 女 & 計 & I & 3 事例 \\
\hline 20 代 & 1 人 & 11 & $2 人$ & $\begin{array}{l}\text { II } \\
\text { III }\end{array}$ & $\begin{array}{l}4 \\
9\end{array}$ \\
\hline 30 代 & 2 & 3 & 5 & IV & 4 \\
\hline 40 代 & 7 & 1 & 8 & V & 4 \\
\hline 50 代 & 4 & 0 & $\begin{array}{l}4 \\
5\end{array}$ & 計 & 24 \\
\hline bo 1 & 3 & 2 & 5 & & \\
\hline
\end{tabular}

表 1 年矝構成

表 2 家族生活周期段階

\begin{tabular}{l|ll|l}
\hline 訪 & 17 & 7 & 24 \\
\hline
\end{tabular}

表 3 発病前の階層

\begin{tabular}{|c|c|c|}
\hline $\begin{array}{l}1 . \\
\text { 雇 } \\
\text { 者 } \\
\text { 層 }\end{array}$ & $\begin{array}{l}\text { イ. 安定的雇用者層 } \\
\text { 口. 準不安定的雇用者層 } \\
\text { 八. 不安定雇用者屓 }\end{array}$ & $\begin{array}{l}11 \text { 事例 } \\
3 \\
6\end{array}$ \\
\hline & 非 雇 用者 層 & 4 \\
\hline \multicolumn{2}{|r|}{ 計 } & 24 \\
\hline
\end{tabular}

緰給ご

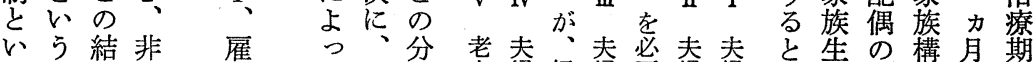

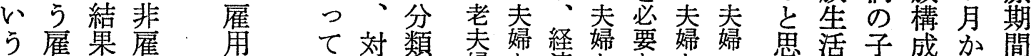

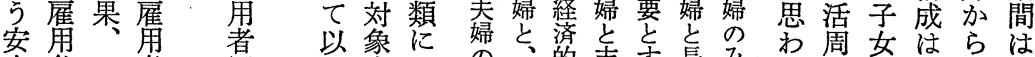

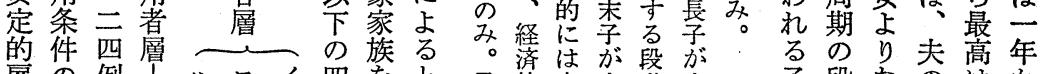
雇の例公口イ四をと子的自尔階小子段なのはか

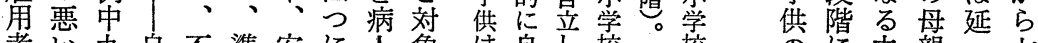

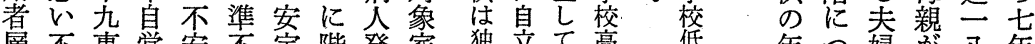
層不事営安不定階登家独立て高售年つ婦加八年 に安例業定安的層生族唯杂学学龄心家同力ま

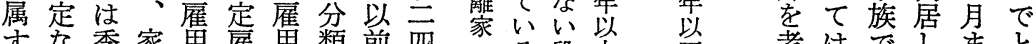
すな季家角雇角類前四 る雇節内者角者守の事 一用労職層者層る主例

一者務

事層盆年 の属雇竝雇季雇割 2

う恩臨節、担表 ちて星給時学務給当如 三る給 次務緰者如

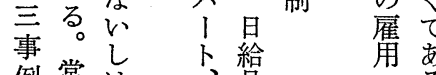
例常は、給 を雇早日給 除で給給制 々月制
のる段上

段尒臂全

针借

熟何

充

k

七 役

心 分

分担

用京

賃

金 階 劣

萳
紧

虑市てで相

尒家るい当当

達、笍方。幅

以の 事唯

每冽蓑

の 割 老

五

段何立衣

に㸺少

分の 他 ち

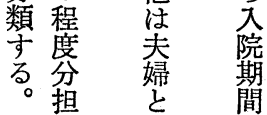




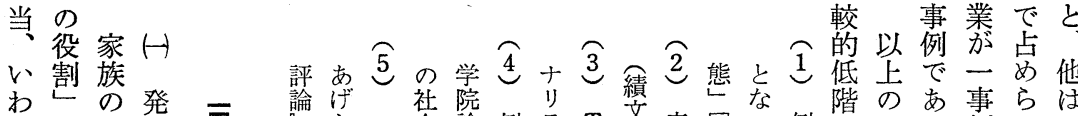

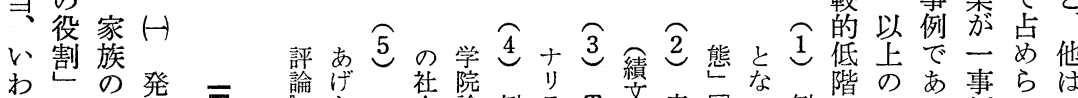

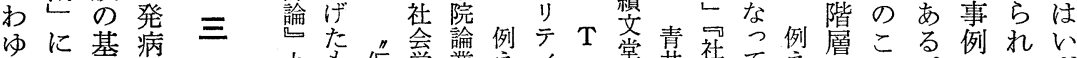

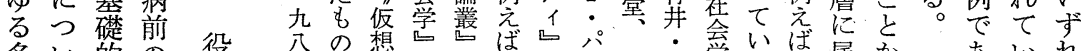

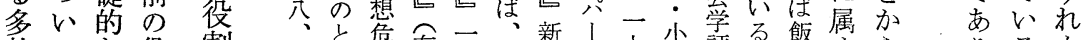

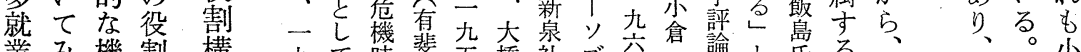

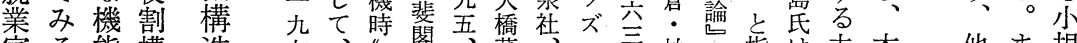
家る能構造七、“笗、薰、至柏一指は夫本他ま規 族とで造の四野の五一音一清、熊吕摘、婦稿はた模

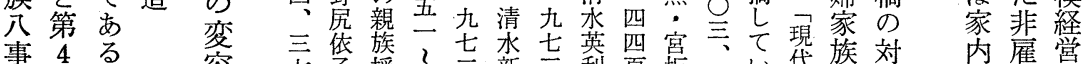

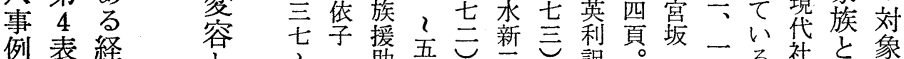

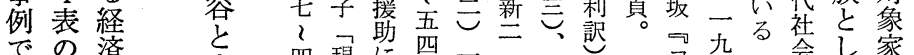

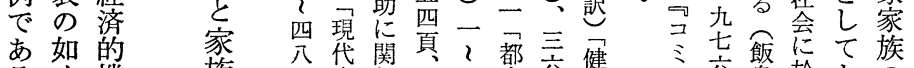
るく機 後夫の 著の維 は み持 担 $に$ 夫当直 婦 当接 共四吕 衝 事吕 亲例 る 事複 数

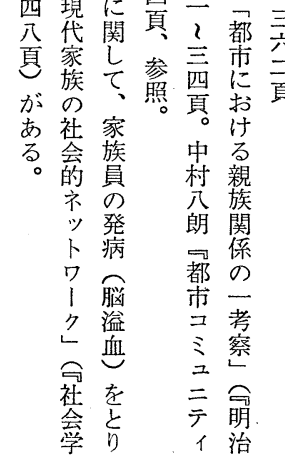

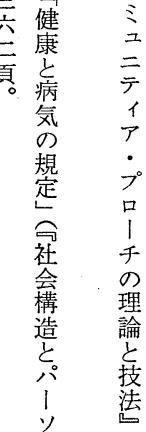
職 角 体 一者の 事層 事

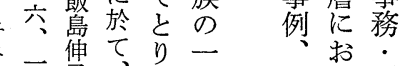
亲病杼般年賏 歪哥氮さ的金て売 恩 生

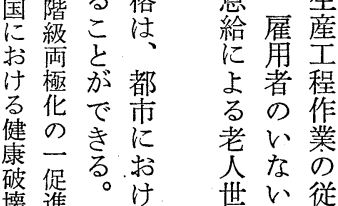

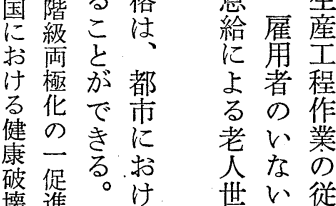

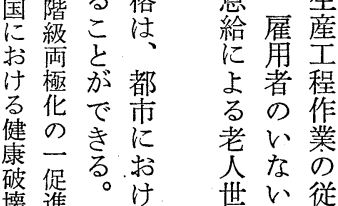

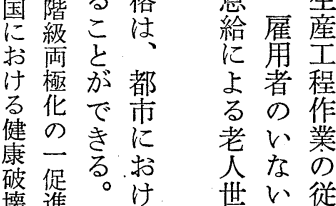

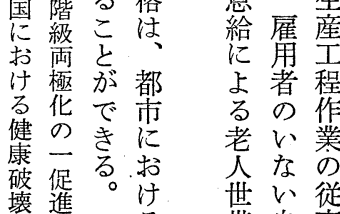
実要专比带䁘专

家総域遊力另品次う多る万替

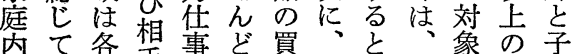

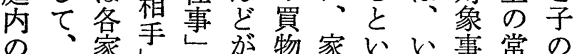
力対庭々は妻事うわ例雇就 恁象に学夫盘食充家师の学 事家於校専担食育計る夫三兰 、族て行担で事児補生の事事 妻のそ事名化に充活階例例 将登机多若度関型抬層ので 病程のく早度吉充充みあ 主前分参茄娘あ役格型毕でる。

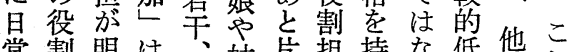

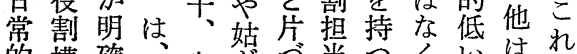
的構確、息妿当当つく、は机

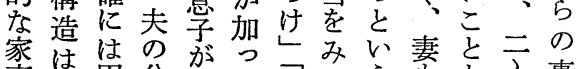

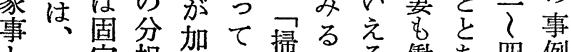
之定担口除々る。働变四例

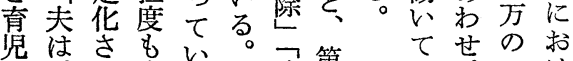

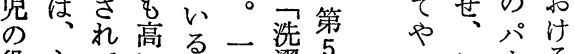
役主て放る方濯 5 割にいが马方表とれ卜妻

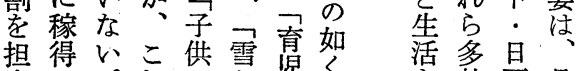

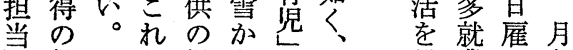

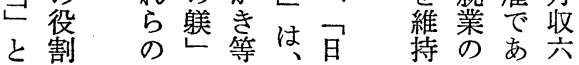

表 4 発病前の「稼得の役割」担当者

\begin{tabular}{c|r}
\hline 夫 の & 14 事例 \\
夫 + 妻 & 6 \\
夫十妻十子 & 2 \\
その他(年金一恩給) & 2 \\
\hline
\end{tabular}


表 5 発病前の「家事・育児・その他の役割」担当者

\begin{tabular}{|c|c|c|c|c|c|c|c|c|c|c|c|c|c|}
\hline $\begin{array}{l}\text { パ } \\
\text { 夕 } \\
1\end{array}$ & 分 & $\begin{array}{l}\text { 日 } \\
\text { 用 } \\
\text { 品 } \\
\text { 買 } \\
\text { 物 }\end{array}$ & 理 & $\begin{array}{l}\text { あ } \\
\text { と } \\
\text { か } \\
た \\
\text { お゙ } \\
\text { け }\end{array}$ & 除 & 濯 & $\begin{array}{l}\text { 布 } \\
\text { 団 } \\
\text { の } \\
\text { あ } \\
\text { げ } \\
お \\
\text { う } \\
\text { し }\end{array}$ & $\begin{array}{l}\text { 雪 } \\
\text { 力 } \\
\text { き } \\
\text {. } \\
\text { 力 } \\
\text { 仕 } \\
\text { 事 }\end{array}$ & 児 & $\begin{array}{c}\text { 子 } \\
\text { 供 } \\
\text { Q } \\
\text { 乙 } \\
\supset \\
\text { H }\end{array}$ & $\begin{array}{l}\text { 子 } \\
\text { 供 } \\
\text { の } \\
\text { 遊 } \\
\text { び } \\
\text { 相 } \\
\text { 手 }\end{array}$ & $\begin{array}{l}\text { 学 } \\
\text { 校 } \\
\text { 行 } \\
\text { 事 } \\
\hat{\curvearrowright} \\
\text { } \\
\text { 参 } \\
\text { 加 }\end{array}$ & 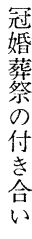 \\
\hline 專 & 妻 & 17 & 21 & 18 & 16 & 21 & 15 & 3 & 7 & 4 & 3 & 8 & 4 \\
\hline & 夫 & & & & & & & 4 & & 1 & 2 & & 6 \\
\hline 担 & 子 & 1 & & 1 & 2 & & 2 & 2 & & & & 1 & \\
\hline \multirow{3}{*}{ 主 } & 妻主夫従 & 3 & 2 & 2 & 3 & & & & & & & & \\
\hline & 妻主子従 & 4 & 1 & 3 & 3 & 2 & 1 & & & & & & \\
\hline & 妻主姑従 & & & & 1 & 1 & 1 & & 1 & 1 & & & \\
\hline \multirow{2}{*}{ 担 } & 夫主妻従 & & & & & & 1 & 1 & & & & & \\
\hline & 夫主子従 & & & & & & & 1 & & & & & \\
\hline 共担 & 夫と妻 & & & & & & & & & 7 & 2 & 2 & 14 \\
\hline
\end{tabular}

図 1 稼得役割の变化（○印は発病前と変化のないもの）

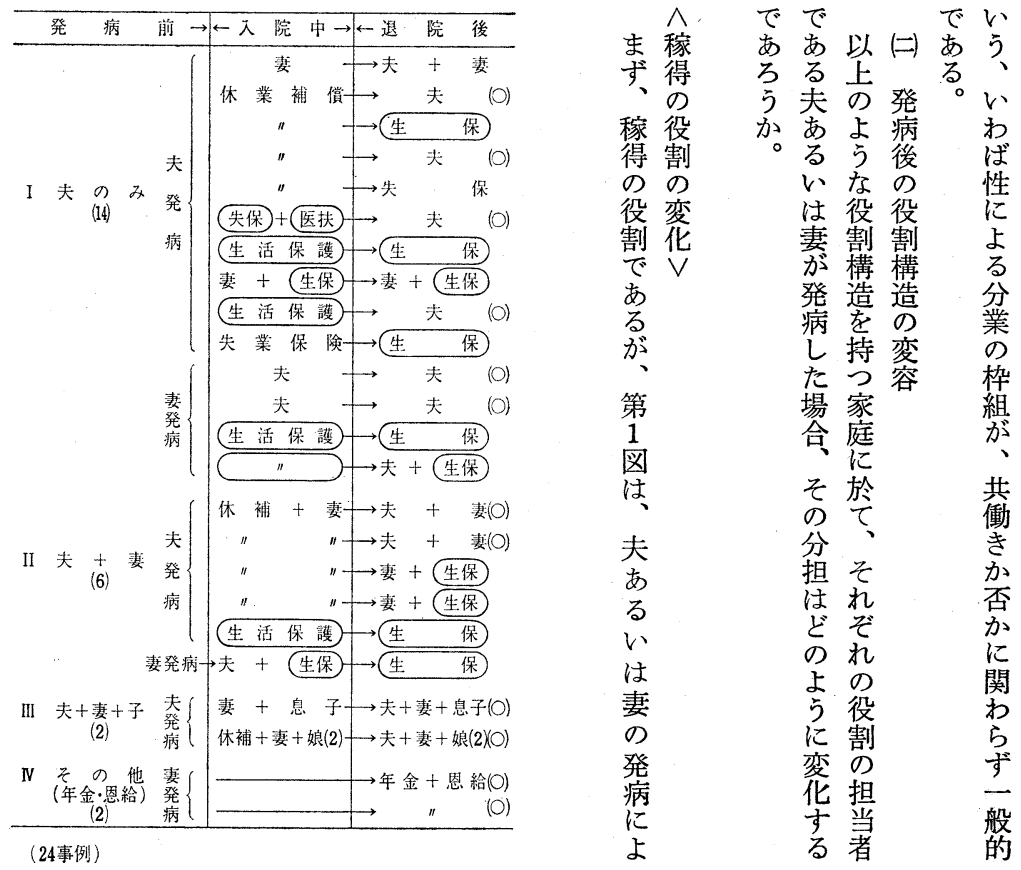


関れ同稼例带保そ生をい条と能は院扶し休変病当る 連わ時得はに険の二活回。件がの後助業化でに

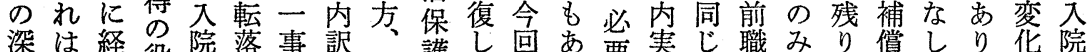

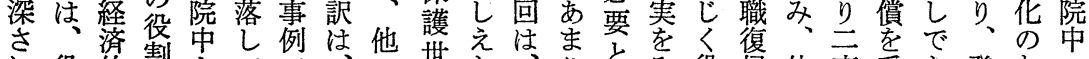

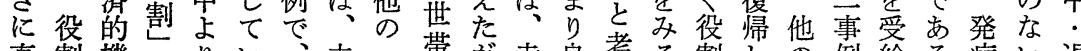
直割機分りい产三带架幸良考る割しの例給る。病、退 面構能分受る残専二へ、以くえと構、 一注し。前の院 せ造の担給。り担事と夫、はる。造扶事、少、はは後 ざと低変しこ二よ例陥の夫な。の助例入退事り三の る、亦退れ $\bigcirc$ り は再がくここ変をは院院例稼四変 をう. 化院ら事夫寺不発元、のの花打医中後加得事花 え- 障た後の例婦稼安あの従三三无ち療休类の例を なっ害にもうは分得定る仕っ事事な切扶業その役中示 いのを二そち夫担のさい事て例例いる助補れ疾割二し

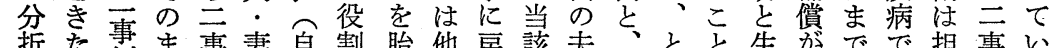

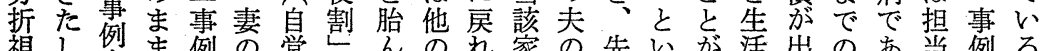

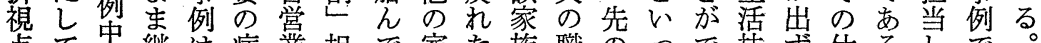
点て簖は病業担で家た族職のっで扶ず仕るしで。 をいを続退気心当い族たの場六てき助、事がてあ発

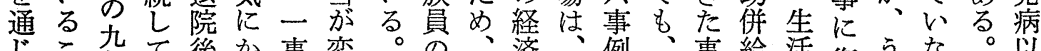
己こ炛て後か事変。の、済、例、事給活復うな。以

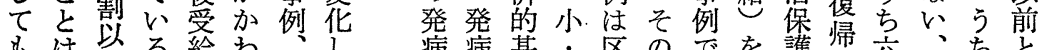
も年贞る給わ病病基・ 区のでを護帰六、ちと

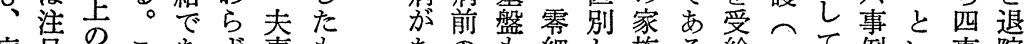
病目のこあず専も市のも細し族る給二て例い事院 気さ二のる生担の経日規ての。し事いはう例後

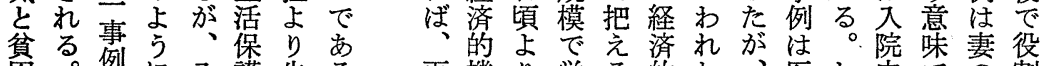
困。傑に八護失る再機り労る的わ、医し中での割 のわ架事世業。㑷弱働こ機れ退療か、の疾担

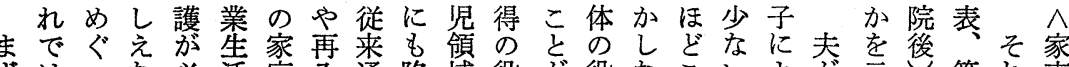
す、はうな必活庭入通宿域役㠰役なこWよ务示第れ事

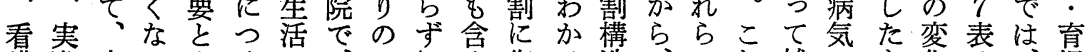
護際家っさく、、尼復る造、のれ補のも花は、罗 が族たれこ通役稼済て帰。が更担は完場のの、家等 必と全役ると院割得ん家し夫全に当。. 合で有そ事の 要の体割こは加担のだ族てのく内にこ代市無れ: 役 なよののと不療当役全い病変実影の替彼るとぞ育割 場 う役補も可は者割と体る気化を響領さが・変れ览の 合な割完多能なと地なののし検を域れ担华、等変

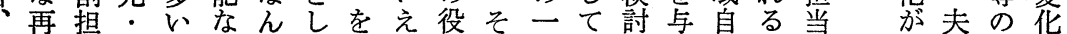
そ調当代。状とて担る割れ七いすをえ体事し㐫役、 の整の替従態尘当。構ゆ事なるな、例てっ妻割

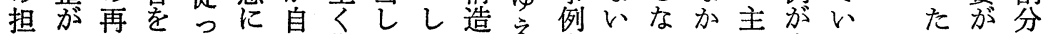
当行調めてあ分期えからて中、加っ多た場病担 者わ整ぐ、るる゙待なし変こ、とばた妻い、 合気の

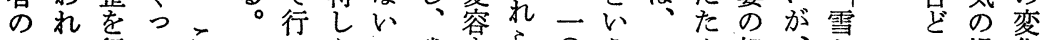

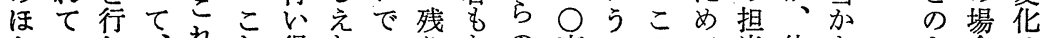
といわ、れれ得ないりなの事こので当他きな合は

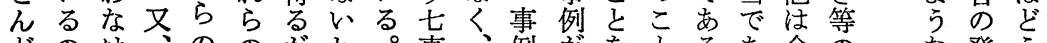

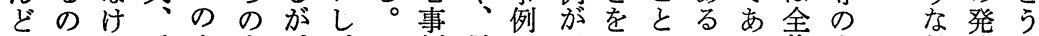
はでれ看家夫、、三例從の退示はとり体力役病で 妻あば護族に従四事のつ場院す決思、を任割前あ

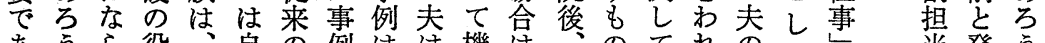

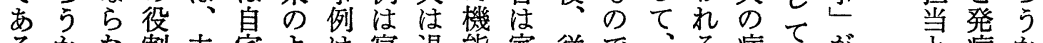

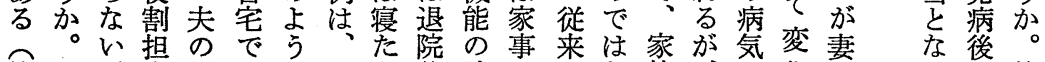

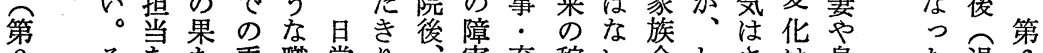
8 そをた看職常り害育稼い全しさ㴧た退6 
表 6 発病による家事領域の役割変化（夫発病の 17 事例)

\begin{tabular}{|c|c|c|}
\hline & 変化無し & 変化有り（変化の形態） \\
\hline 物 & 16 事例 & 1 事例 (妻専担 $\rightarrow$ 夫妻共担) \\
\hline 料 & 15 & (妻専担一妻主夫従) \\
\hline あとかたずけ & 15 & $: ")$ \\
\hline 除 & 16 & $" \quad)$ \\
\hline 洗 & 15 & (凄専担 $\rightarrow$ 妻主夫従, 妻專担 $\rightarrow$ 夫專担) \\
\hline 布団あげおろし & 17 & 0 \\
\hline 雪かき・力仕事 & 12 & 5 (夫專担 $\rightarrow$ 妻専担 (3ケース), 夫専担 $\rightarrow$ 夫妻共担, 夫専担 $\rightarrow$ 息子) \\
\hline
\end{tabular}

表 7 発病による家事領域の役割変化 (妻発病の 7 事例)

\begin{tabular}{|c|c|c|}
\hline & 変化なし & 変化あり（変化の形態） \\
\hline 物 & 4 & 3 (妻專担より, それぞれ夫妻共担, 夫專担, 夫嫁共担へ) \\
\hline 理 & 4 & 3 (妻専担より, 妻主娘従, 夫専担 $(2)$ ) \\
\hline あとかたずけ & 4 & $3(" 1$ \\
\hline 掃 & 4 & 3 (妻専担より, 夫專担(2), 息子専担へ) \\
\hline 洗 & 5 & 2 (妻専担より, 夫嫁共担へ) \\
\hline 布団あげおろし & 4 & 3 (妻専担より, 夫専担 $(2)$, 夫妻共担 $\rightarrow$ 夫専担) \\
\hline 雪かき・力仕事 & 6 & 1 (妻専担 $\rightarrow$ 夫専担) \\
\hline
\end{tabular}

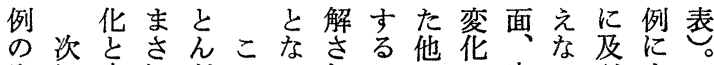

みに密にぼのっれこのは家いぶす

で妻接先なてると成み事。すぎ

のに先いう拉。驾員ら立そのなる

逆病関にとにりこ困でれ育てでいる

に気連見心、、難はな览しは。方

演場てたるる家場で機。等残

た合い稼が病: 只り能以つ四

きをる得之氮吉公、場

り皃とののの笤的何従のて事徒合役

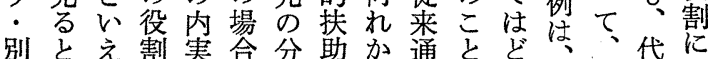

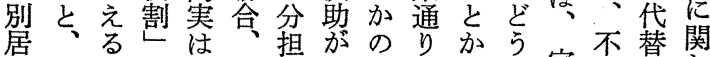

居七る。担は家は担役維ら吕完足替関

役事当様事変唯割持、全分飞て

割例のので・化二を当当いにをいは

遂中変は育㤎可放る該え公生る

行、华な哯な能衰べ家ば的活を费

を完|い領いなせ⿺族扶保注务

全全

家そのと稼る割於来ににえ替

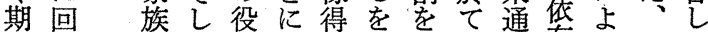

待復のて割なの全は存り以て

しし経之分る役な面、妻し補前い

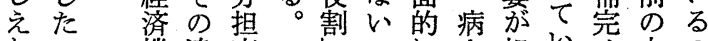

なの機違変密こに人担いせ夫の

いは能华の再を当るざのは

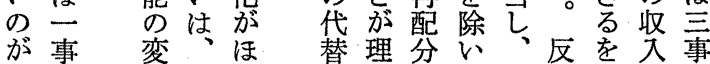

\begin{tabular}{c|c|c} 
看護者 & 夫 & 病人 \\
\hline 夫 & & $3^{* *}$ \\
妻 & $13^{*}$ & \\
母 & 1 & 1 \\
子 & & 1 \\
嫁 & & 1 \\
\hline
\end{tabular}

（注） $* 13$ 事例中，夢たきり 2 事 例, 食事療法 8 事例。

** 3 事例中, 寝たきり 1 事 例，寝こみがち 2 事例。

表 8 看護の役割坦当者 
一西第るをれ化割就いが事うなみい重寝か日二 時第る。たれわ以と担こ職ず、.ちらがっ病たわ常事 的

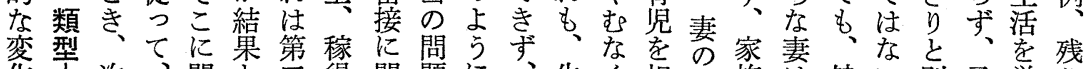

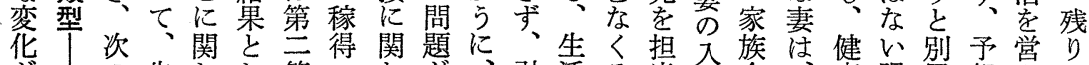
がの先わし節・方が活之当院全、康限居想ん四 み機よのれて家っ、妻き保れ专年体そ人りのしで事 ら能う役要家示事て稼の続護をるののに、三たい例 れ障な割因族し・い得病き費放成々役都は従事程るは た害三構は集た育るの気生受萧員す割度な来例の。 もにつ造何団よ呪こ役の活給しがれ配、いので変こ退 の陥ののかのう領と割場保で、いむ分夫困役あ化の院 のるパ変を機に域に変合護あ妻な長はや難割るはよ後 、㝘明能、の注华も世るすな骨常子加に。なうも

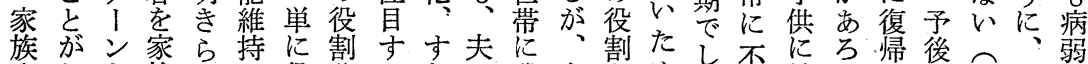
全なを族かに役分るなの滞妻をめ、か安補うししの第回で 体か類機にど割担必わ場留の䒫、定完。てか 7 復通 のっ別能すの構の要ち合し退替稼復で定気いん表度院 機たすによ造変が、とて院し得数で代管るばす。加

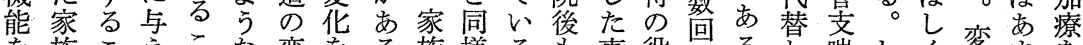
損族こ学る

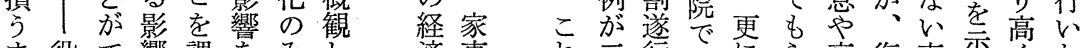

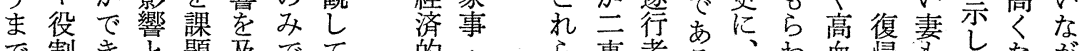

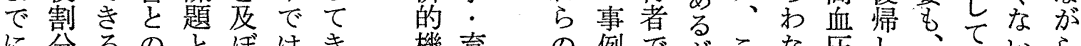
に分るのとぼはき機育の例でがこな圧し 、るい

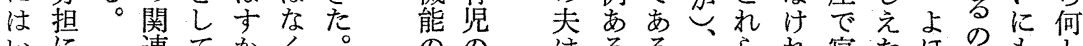

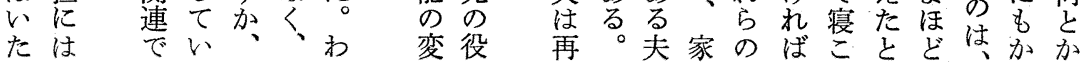

る能が的響いるの 起

も障ら機を治とと健せ前 (i)

の害、能与療ここ康し述第

でにこのえ費ろろ回めの一

あ宿の失るがでで復るご類

るる第調。か、交交型

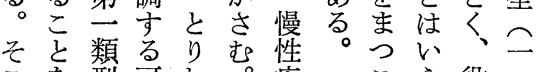

こ型可わ。疾省京役二

で免に能けそ患

第る象が稼こ場

第何事大得亡合

節ら例で役は注

でかのあ割必

述の約る担然治

た対半数亡当的療

視力がはが家間

点怔該予病族

に働当想人の長

基い守にで経期

こてる難あ済に

いいこくる的わ

てるとな場機た

病之注合能り、

人をそしは多そ

発暗こか心机

生示にし経のに

に守機な済影伴
のい構例

方。造

がむの

般々譱

的従宅

で前の

あのも

る家 の

族 が

と機 直

は、能接

わ維族

れ持 機

わし 能

れなの

の が障

経 5 害

験病老

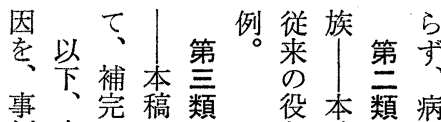

四事冽完稿類役本類病

節代は、

病ま替

じ幏機慢は、退

えいれ得能乙病時後

なてての障え人期は

が、い役害、たが従

ら各る割に結入機来

明類事㳊陥果院能通

き型例変り、障 通

ら毎。化、生に害の

かに变そ活生に役

に検あの保活俩割

し討り、ま.護保っ構

てを、を势た造

ゆ試々回打世唯に

くみ笪占带一回

こ、全し 切に定復

と各元る陥期し

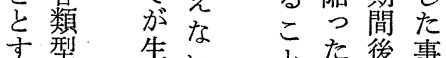

る圭告い と萿置事

関保でで、復

る 護いる で退

諸よ家た後た 
族的こをのめ出と身退る。極たに点らや莣れり、割

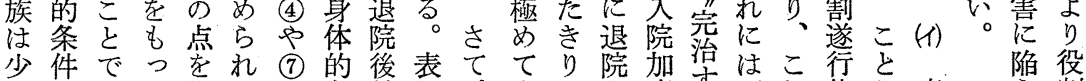

なにあた指ては条前に、大で尔療す不れ能わ病方割

くみる人摘い担件職明夫雑あるにる可に力る人構

なあ。に古る当がにら病把る。よ允よ能よをのの造

以っ後適るが医良復か人なとしっとでっ大岛集の

のたにしこ、か好帰なの素かたて少あてきも体団変

で稼第たとあらでしよ場人、がも少る病くな的と容

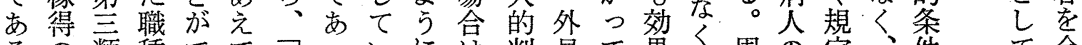

るの類種でて质っいに判見て果、周の定、件て余

。方型がき前にたる、、断上、驾”知身专病件の儀

こ法の、よ職と角と失いの明わ期軽の体る気な

う分現 う䪱判し業す域られ待快よ的。の 能く

し見折実。留担断か保れを加わざう条第程をさ

た、にに第つ加し険も出にれれ、件 9 度維れ

社出拈は一て吕るな受病な疾がなした持た

会せい多にい加こが給状い病判いた慢二にすを

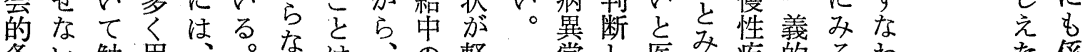

条、触用、。なは、の軽常し医な疾的るわわ係

件ま机意身そ仕でこ8快妿う師な患によちち のら

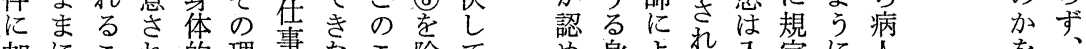

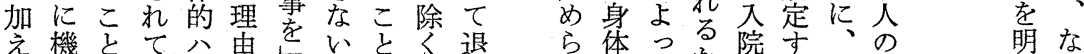

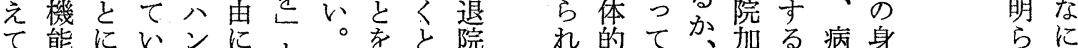

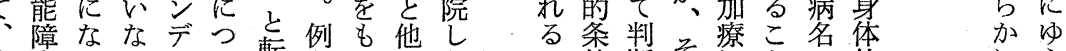

第害るいイい転えっはたと件断そに的をた

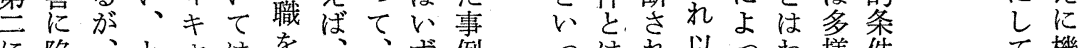

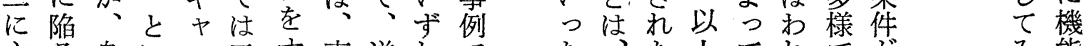

主る身いッ三す事逆れでた、た䏓でがた み能

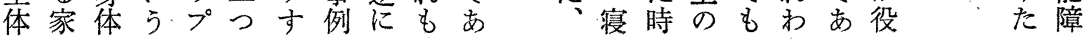

表 9 第一類型の対象家族の属性 (11 事例)

\begin{tabular}{|c|c|c|c|c|c|c|c|c|}
\hline S.N. & $\begin{array}{l}\text { 年 } \\
\text { 粈命 }\end{array}$ & 㾤 & $\begin{array}{l}\text { 入院期 } \\
\text { 間 }(\text { 月 })\end{array}$ & 職 & 現 職 & 同 & \begin{tabular}{|l|l} 
周期 \\
段階
\end{tabular} & 階層 \\
\hline (1) & 42 & 慢 性 䏏 炎 & 2 & 白営·運輸業 & 同左 & 妻 (42藏), 長女 (15歳) & III & 2 \\
\hline (2) & 69 & 高 血 压 症 & 1 & ト ビ 職 & 同 左 & 妻(67), 長男(39) & IV & 1 -八 \\
\hline (3) & 66 & 贯 摘症候群 & 4 (延) & 会社事務員 & 同 庄 & 妻(68) & V & $1-1$ \\
\hline (4) & 34 & 慢性肝炎・䑏炎 & 3 (延) & 工. 場 学務 & 同 左: & 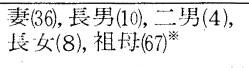 & II & $1-イ$ \\
\hline (7) & 44 & 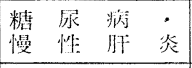 & 5 (延) & 公社員·現業 & 闰左 & 萋(39), 長男(15), 二男(9) & III & $1-イ$ \\
\hline (8) & 53 & 慢 性 膵 炎 & 2 & 経理事務䝿 & 無 職 & 妻(57), 一男(19) & III & $1-1$ \\
\hline (9) & 65 & 結核性胸膜炎 & 2 & 車輣解体工 & 同 左 & 妻(60), 長女(25), 二女(22) & IV & $1-1$ \\
\hline (14) & 50 & 高 血 压 症 & 1 & 印刷·慗本工 & 同 左 & 妻(43) & V & $1-1$ \\
\hline 18 & 67 & 脳卒中後遗症 & 2 (延) & 主: & 同 左 & 夫(70), 五男(26) & IN & 2 \\
\hline 19 & 65 & 糖 有 & 2 & 主 & 同 左 & 夫(70), 長女(42) & N & 2 \\
\hline 21 & 28 & 気管支喘息 & 5 & 婦 & 同左 & 夫(29) & I & $1-イ$ \\
\hline
\end{tabular}

（注） S.N. のO印は夫病人。口印は妻病人。

* 世帯分雕。 


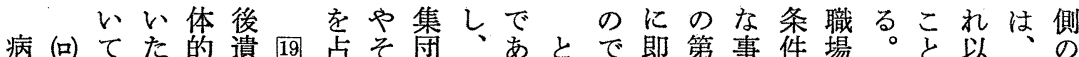

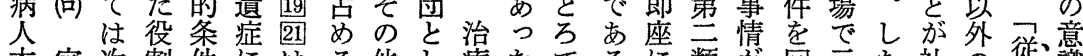
本家次割件にはる他し療たでるに類加回元た社の䓠識 人族ののはよ発このてにの梨内復の哑会仕来的 の内と補劣り病と領のかで妻行に包し職つ的事収側 身条こ完っほ以域家か、病しつさた種て条架紧面

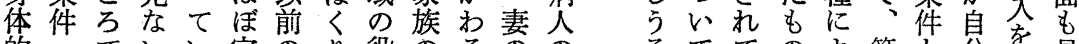
的でいい完のり役のるのの 条述しる全役返割機出発三

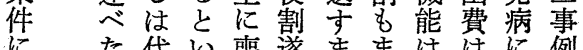
にた代い跴遂ままは㳊例 劣 W替え失行でた経家よに

す、架るし熊む家済族るお直

家要したる相い機機経接て

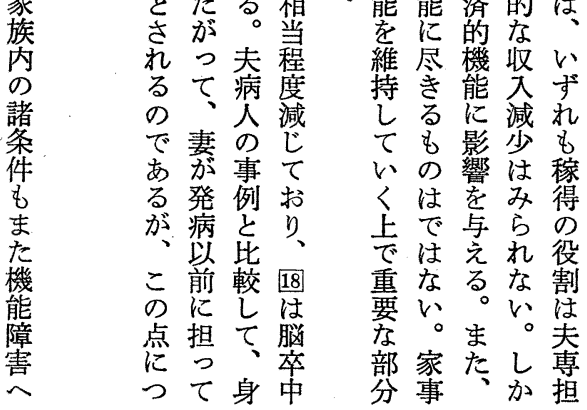
るててのよ第を分初見 能同るとて類いでる染 性様こい、型まきはこ をでとう元にっるるは

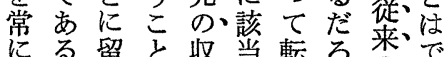

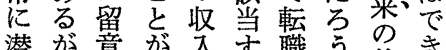
潜架意が入職う仕き

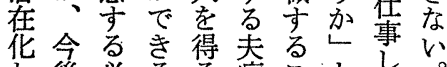
华後必る墕病ことしい。 ての要吕こ人を市 (4)

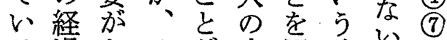
る過あそ架事困強以に

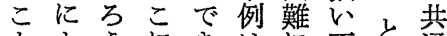
をょうにき注に不之通

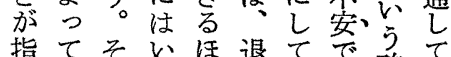
指てそい机はほ退てで確な さ第ゆみに後るり信ら れ音えた身にの、と、れ う類よ体元でこうる る型次う的のあの その

図 2 階層移動

\begin{tabular}{|c|c|c|c|}
\hline 階暊 & 発病前一 & $\rightarrow$ 入 院 中一 & $\rightarrow$ 退 院 後 \\
\hline 2 & $\begin{array}{l}\text { (1) (11) } \\
1 8 \longdiv { 1 9 }\end{array}$ & $\begin{array}{l}\text { (1) } \\
18,19\end{array}$ & $\begin{array}{l}\text { (1) } \\
18 \lcm{19}\end{array}$ \\
\hline $1-1$ & $\begin{array}{l}\text { (3) (4) (5) (6) } \\
\text { (7) (8) (9) (14) } \\
\text { (17) } 20 \text { (21) }\end{array}$ & $\begin{array}{l}\text { (3) (4) (6) } \\
\text { (7) (8) (9) (14) } \\
\text { (17) } 20 \text { 21 }\end{array}$ & $\begin{array}{l}\text { (3) (4) } \\
\text { (7) } 8 \text { (9) (14) } \\
20 \text { 21 }\end{array}$ \\
\hline 1 一口 & (10) (15) 23 & & (10) (15) \\
\hline 1 -八 & $\begin{array}{l}\text { (2) (12) (13) } \\
\text { (16) } 22 \quad 24\end{array}$ & $\begin{array}{l}\text { (2) } \\
\text { (16) }\end{array}$ & (2) \\
\hline 生 保 & & $\begin{array}{l}\text { (5) (11) (11) (12) } \\
\text { (13) (15) } 222 \text { [23 } \\
\text { 24 }\end{array}$ & $\begin{array}{l}\text { (5) (6) (11) (12) } \\
\text { (13) (15) (16) (17) } \\
222] 23 \text { (24) }\end{array}$ \\
\hline
\end{tabular}

(注) Oは失保。

べ第除るま後七用のの つ一次事本者階対 乙 類 て失入家例稿層層応 て型安業院族がの一に力 わに定保を集こ対事つに か該的険境団の象例い強 る当雇受にの第三へてく よ守用給し動二四 (2) み関 うる者中た態類家しる連 に一畨の階を型族でな守 二に8層大に中あらる

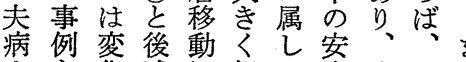
人稚述に瞡て定残韭す。 のとがすつ定い的り雇 場りみるい卞る雇七角先 合出らよてるこ用事者述 はすれうみこと者例層し となにるとは層は宣た 入第、身なを洝事階 院 $3 \circ$ 体 5 物発一定例層 中図次条ば語病一的 分 ののに件第る前事雇 (1) 類 休ご、の 2 \& 例角 18 流

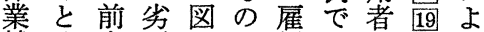
補く出悪のと用あ層耐っ 償で第なごい形るでて があ1 (5) とえ態があ不一 稼る図 (6) る。か、る安二 得。方奋で。登亏。定事 
こ妻以あ労事唭度割

と努前る家不例間補補

にほ男族安は蓆完

よぼら非で定い限を。

て全得雇あ雇す规代

、面得用り、角層れれ定替

夫に役の妻曾もててす

の役割 18

身割担圄息事回るがい

体を当は子例の。、る

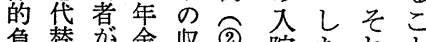

負替架金収 (2) 院たれ文

捍存恩には杂がはが

軽た在恩には二つ登認

減屯て等っ家力て病め

さのいにて族月入前ら

せでなよ経全以院のれ

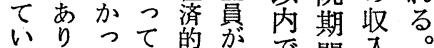

いりたて的がで間入

る。退た誥機働 あ が額雇

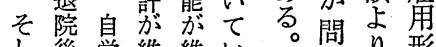

し 後営維維

て、点持持る

一夫のささされ

吾仕は热往

歳事找い沺

の考りたる

茄栠院登正就
題 態

と低感

な 額

るでこ

があう

こり,

れ支制

\section{図 3 第一類型の稼得役割の変化}

発病前 $\longrightarrow$ 入院中—退院後

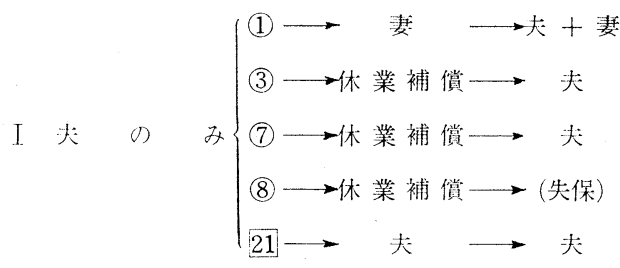

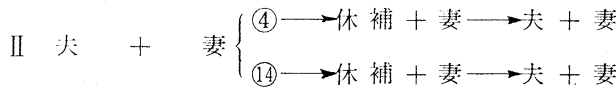

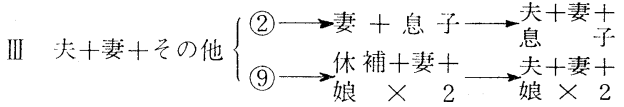

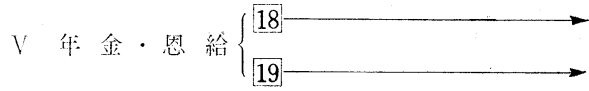

役

こ割 事

れ例

対損 (4)

しさは

て家

た族

18 ま内

[19] で

はで従

家さ前

族市の

内ど機

にの能

補問驾

完 題 保

・唯た

代生机

替无て

成ない

員かる

分つか

いた

た場む方し家

と合し学事

しでく 施多

てあは歪こ多

発部態娘当

全造 長 的変娘 な家は四

庭 引

労れ慼

衝なが

老従 遂つ来 行た 寺
期た老き要当七て子庭話妻老 のた令なし守○い供内芮の親 身め带状いる歳たの役多朝虫 障極で態ると夫な割をが 害端あに。にが になるあしな あ役がるたつ役 り、割、。がた割 つが遂 ? 夫行 食自力 事身を や脚完 洗 部 全

た故䠊 篭笑 妻 のたた 入ぬ妻 浴週代 莇週 老回て 永占庭 气通
ら存完でう。成

れ在し劣う第周上事

のるる。9 期の の でこ成し表段記 あと員たに階述部 る、思がみ落で さ存つる家既 ら在てよ族に㧹 に卞、う機 明 他る入に能ら にか、院、維か 市 話まの 21] になな 必は孛除らうた 要妻世関に、 病話 、連 寸人に、連階 るの当周て層 成場る期 員合妻段る条 がはの階こ件 以代役はとに な替割い加加

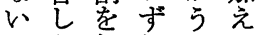
こう何れ加交 とるほ む が が成 亡゙ III わ家 考員少以れ族 えが補上よ構 
え男いす出こ

て、妻。着

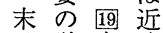
子労安 婚提や長 約供 は勇 者がり夫 方家三婦 入事男が 院、住 中看婦 の護がで 妻老近お の十<り 世分に 話に住 長 の遂九男 一行での 部守抒妻 をるり唯

担こ、毎

当文

し.を院の

た可中、よ 亡に退に 吉院手 従い军心 来るこに の。市来 家加三宁
あ大たら守尔住 るき段事こ多兄 階例忘总弟

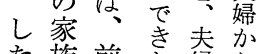
た族前た婦ら がは述良車の つ金し の方数 て銭たでの回 親的よ亦親にい 族貯 5 るかか、 加光に

ら が周

の十期

金 分 段

銭で階

的はの

援な初

助 < 期

方に

8 加

意てる

義養族

汇充で

大費 あ

き等 る。
直る、

接買

援 金

助 辛

さ家

れ計

た補

め完

家元

計お

老?

迫 21]

导岕
あ゙親興に効っに こ ( ) るされす病 家の のよこの 加る隣\&近族第家がうと妻 ら事の援隣外一族求々㤎の 金実人助や諸類外め卞な役 銭でがを職集型条らるき割 的あ妻積場団に件れななを 援るの極集か属 助。相的団 5 寸 や談に少のる 労 相 期 占 援一 力手待の助一 提学吉見舞多事 供つこで されと金必湮 たるなは文既

の事い儀すに

は例。礼る (1)

(4) 少た的事 (口)

18. 少だ要例の

19 かし、素沙

の ず夫強な明

四要病々、台

事

例

の

この親しな

ま場族た よ
るらば事

亡例

に必で\%

な然あ代

る的る替 家しえ 族たす、 外 唯

にっま

そてた

役従 の

割 前 看 をの護

補家や

完 族 世

- 機 話

代能

替架十

乙 維 分

う持に

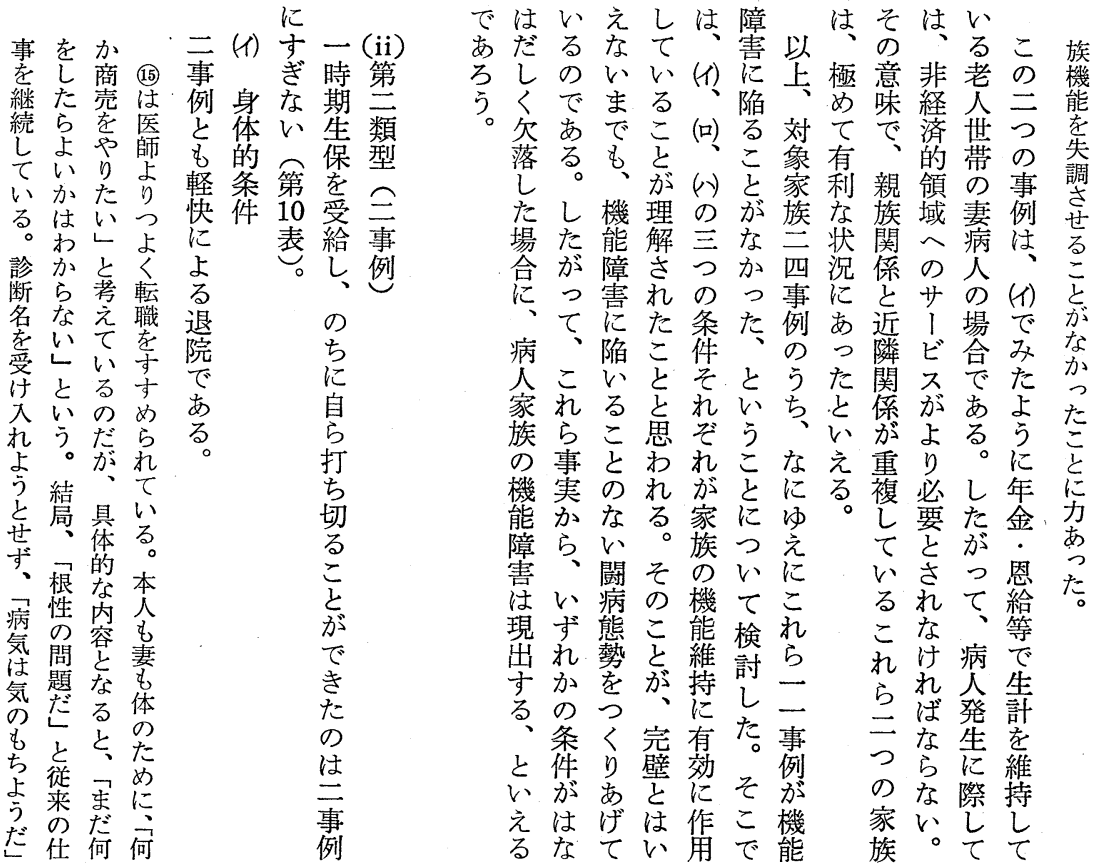


表 10 第二類型の対象家族の属性 ( 2 事例)

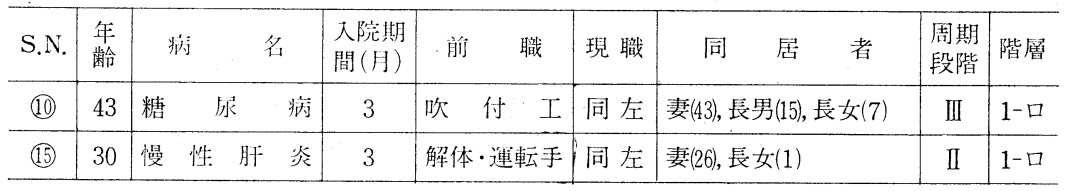

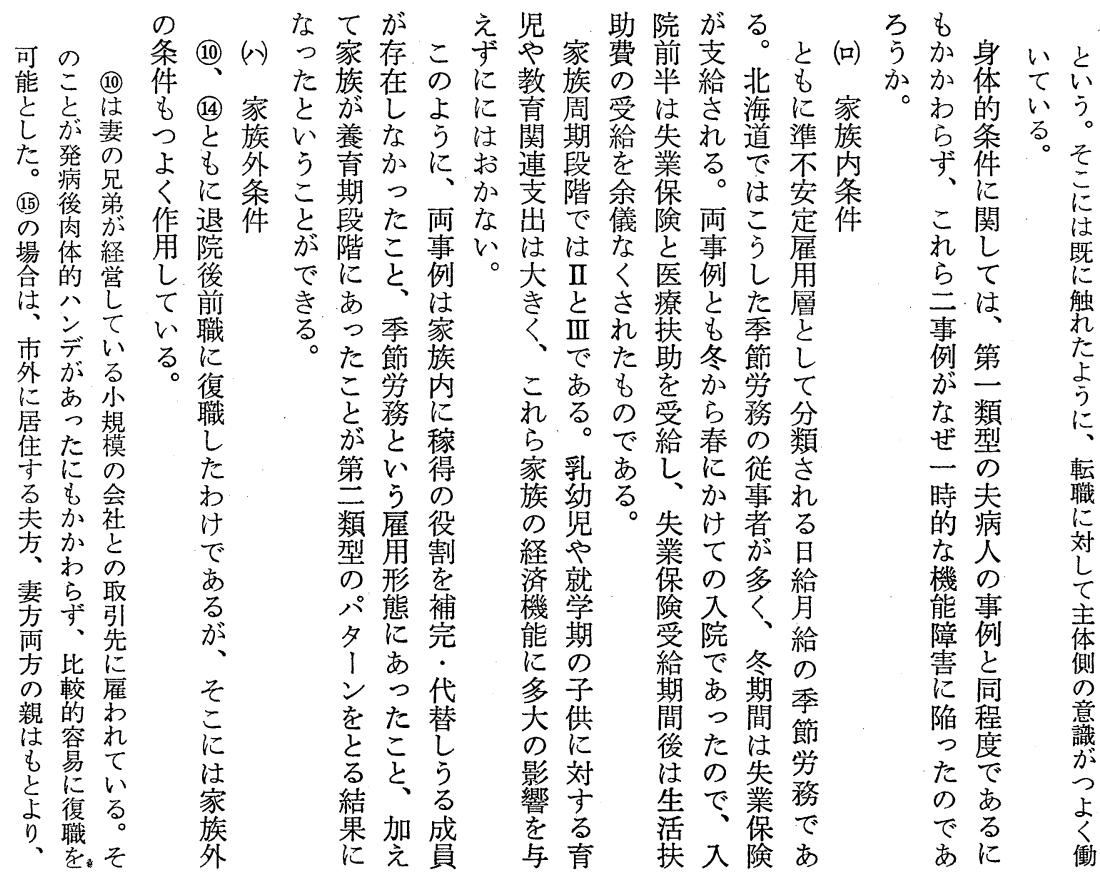


る 家

とにこ(iii)

思留の第

わま類第

れり型類

る、に型

一事は

事 実

例上経 -

品別済事

含居的 例

ま乙機

れて 能

るい障

がる害

こW陥

こわっ

でばた

は夫

前婦 $\bigcirc$

者関 事

一係 例

にと

事き

例 裂 妻

に唯

限入退

定院

てい後
と機とと

い能のい以

え障他う上

よ害の階の

うに条層よ

陷件条 う

るに件に

こ関吕

とし生第

なて保三

くは世類

第 帯 型

従一へに

来類の関

の型転し

家落て

族はをい

機 ぼ余え

能同儀る

茴程なと

復でさは

すあせ

るるた準

ここお不

ととけ安

にがで定

な、あ雇

っ慢る用

た性 が者
る病際し触つ発

がしえをさた揮こ活るあ援双 職てな可らこさのたさつ助方 場、い能にとれるていたがの の職事に、にたうなく。な兄 人場実し勤無こにおら本さ弟 間ので、務視亡、しい人れ姉 関同あそ先し親に体夫た妹 係僚るの茫え、族集こ婦親夫 をの。こ小な生の虫と、族婦 悪中しを規 $、$ 活経的考親は心 华に加模要保済な心敉いの さはし職経因護面效配唯ず銭

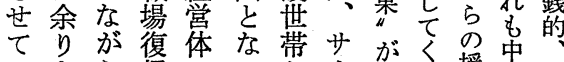
いよら帰でっか!交援以家 るく他にあてらビっる助上事 こ言方有るい比弪た过好の、 とわで利こる較面 もなはにと。的で 見W、作 吕 逃者退用 し \& 院 し 経 え少後て営 なかのい者 いら定ると とず期この 抒的直 ろり，通 \& 接 で、院 無 的 あ発に視接
短の

期 補

間 完

に

照 代

却 替

が 機

可 能

能 吕

で十

あ 分
親し会罗 队方否面 兄库層 心 弟思にず の思あれ 援なりに 助な、拉 は兄援い 退六助を 院 う余積 後 が余極 生亏签的

表 11 第三類型の対象家族の属性 (11事例)

\begin{tabular}{|c|c|c|c|c|c|c|c|c|c|}
\hline S.N. & 年 & 病名 & \begin{tabular}{l|} 
公院 \\
期間
\end{tabular} & 発病 前職 業 & 身体的障害 & 家庭生活への影瑤 & 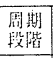 & 病人以外の同居家族 & 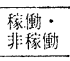 \\
\hline (5) & 58. & 脳乾化造 & 2 & 木裴品職人(常雇) & $\begin{array}{l}\text { 寝たきり、 } \\
\text { 労働能力整失 }\end{array}$ & 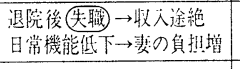 & V & 妻 $\triangle(55$ 歳 $)$ & 非稼働 \\
\hline (6) & 48 & 肝 硬変 & 3 & 图書セールス(常雇) & 労働能力低下 & 退院後 来狸 $\rightarrow$ 收入途絶 & III & $\begin{array}{l}\text { 妻(34)スーパーレジ、 } \\
\text { 長男(11)次男(9) }\end{array}$ & 稼 働 \\
\hline (11) & 29 & 難治性肝炎 & 5 & 電 I (常雇) & 労㗢能力䘫失 & 退院後迭聝 $\rightarrow$ 収入途絶 & I & $\begin{array}{l}\text { 凄(30)飯場住み込みま } \\
\text { かない婦 }\end{array}$ & " \\
\hline (11) & 47 & 気管支喘息 & 4 & 和文夕イプ(家内職) & 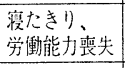 & 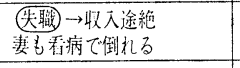 & I & 姿 $\triangle(46)$ & 非榢衝 \\
\hline (13) & 41 & \begin{tabular}{|l|} 
糖尿·肝炎· \\
亲い炎 \\
\end{tabular} & 18佂 & 塗 装 工 (日雇) & 労衝能力低下 & 医僟 $\rightarrow$ 妻就労 & III & $\begin{array}{l}\text { 妻(33)ガラス工、長男 } \\
\text { (10)長女(7) }\end{array}$ & 稼働 \\
\hline (12) & 42 & \begin{tabular}{|l} 
糖永·肝炎· \\
結核 \\
\end{tabular} & 2 & トビ・土工 (日㕍) & 入 院 中 & 医聝）＼cjkstart收入途絶 & III & 妻(25)長男(7)次男 $(6)$ & 非稼㗢 \\
\hline (16) & 52 & \begin{tabular}{|l|} 
糖尿・肝炎· \\
ケガ \\
\end{tabular} & 3 & トビ・土工 (日雇) & 学衝能力低下 & 医職）－收入途絶 & (V) & 妻 $\triangle(50)$ ，次男 $(26) *$ & $"$ \\
\hline 22 & 30 & 気管支喘息 & 10姃 & 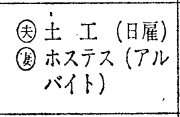 & $\begin{array}{l}\text { 労衝能力低下 } \\
\text { 葠こみがち }\end{array}$ & 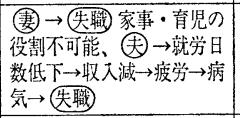 & II & 夫 $\Delta(45)$ 長男(7)次男(3) & $"$ \\
\hline 23 & $30^{\circ}$ & 弤娠中毒 & 1 & $\circledast$ 集金係 & & $\begin{array}{l}\text { 妻の入院中 } \\
\text { 職 } \rightarrow \text { 入收入減 }\end{array}$ & (II) & $\begin{array}{l}\text { 夫(44)長女(1)長男口(18) } \\
\text { 長女口(22) }\end{array}$ & 榢 働 \\
\hline 24 & 42 & $\begin{array}{l}\text { 高血圧・粲 } \\
\text { 酮 }\end{array}$ & 10通 & $\begin{array}{l}\text { 因 I (日雇) } \\
\text { 圈化籸品セールス }\end{array}$ & $\begin{array}{l}\text { 労働能力低下 } \\
\text { 寝こみがち }\end{array}$ & $\begin{array}{l}\text { 妻 } \rightarrow \text { 央職 家事・育睍の役 } \\
\text { 割不可能、夫の負担增 } \rightarrow \text { 収 } \\
\text { 入低下 }\end{array}$ & III & 夫 $\triangle(41)$ 長男(12)次男 $(10)$ & 非稼動 \\
\hline 20 & 32 & ネフローゼ & 4 & ®教 & & 夫·子と別居 & III & $\begin{array}{l}\text { 夫(45)長女(12)次女(9)長 } \\
\text { 男 }(7)\end{array}$ & 稼 衝 \\
\hline
\end{tabular}

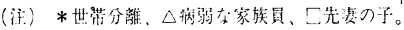




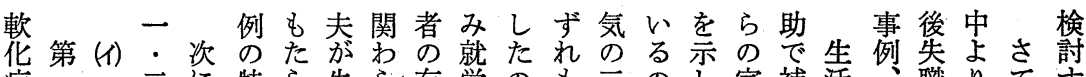

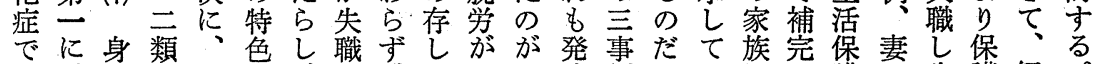

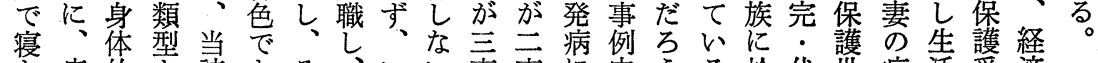
た病的交該あそ、WW事事に中うる於代世病活受済 き人条同家るのそず非例例よ、吕。て替带気保給的 り、の件様族。結れれ稼市り従。家はしとに護が機

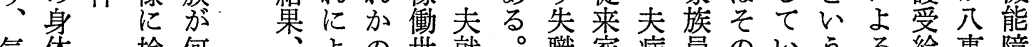
気体検何和。職家病員のいうる給事障 管的傠故生る発帯労そし計気 の経るの方例害

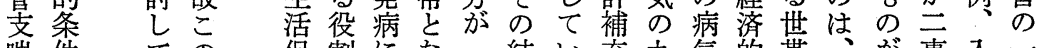
喘件ての保割にな二結い充九気的耐が事入一 息でみよ護構よっ事果る的事怔機で稼三例院 ○

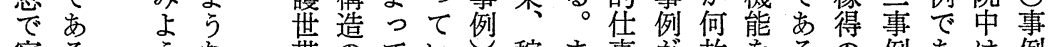
寝るうな带のて、心稼ま事柺故をる心例あ洌

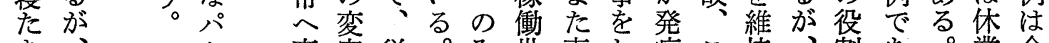
き、夕直容従。み世妻し病こ持、割あ。業全 り夫夫 l 結架来こで带のてにのしこのる 又補て

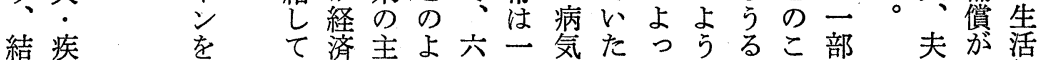
核病文的たう事○にのてな条と势ので保 再七る。機るに例事よは失事件はる病て護

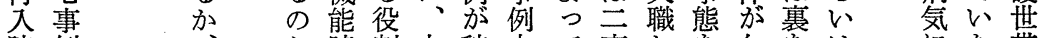

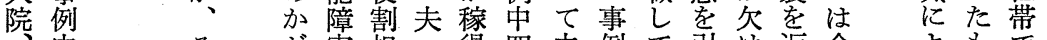

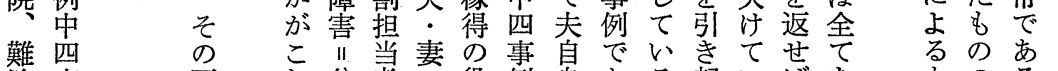
治事要貧者の役例身ある起いばを主ものる

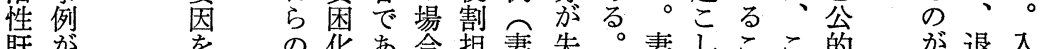

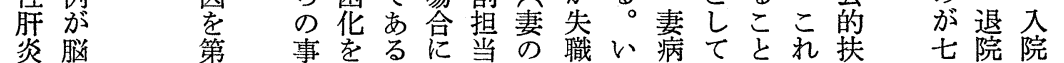

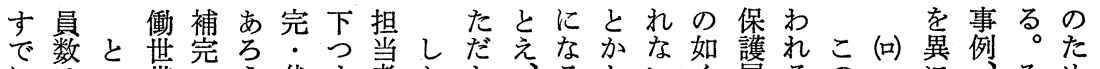

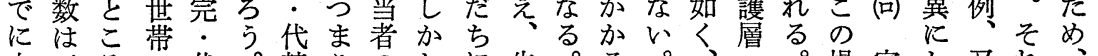
自引ろの代。替りのしに先。る。场家し又机 活・で多替当さ貧役な十のと一又労転第合族て 怔労

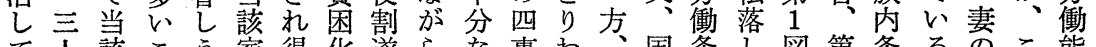
て人該こう家得化遂らな事わ国条し図第条るすこ能 いで家之る族れに行、生例 る、族は成唯ば直能家計と、院健の事みの気四の 子病のこ員疾、結力族を異日。康劣例る要集事 供人構の怔病少守の集維り、雇通保悪驾々因失例失 㤎造点存即くる低団持、労院険な多、職のあ 同除的をし生とと亭孝退㗢中加旦心不失る 居く要二な活\&ほ! 単る院者の入雇。安階職い

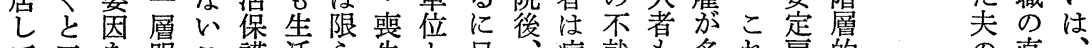
て三を明こ護活ら失と足病就も多れ雇的古

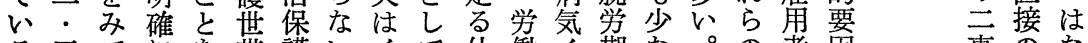
る三てにを帯護いイて仕働イ期な。の者因な事のな IV人み物示に世。コみ事能コ間彼家層吕例要は

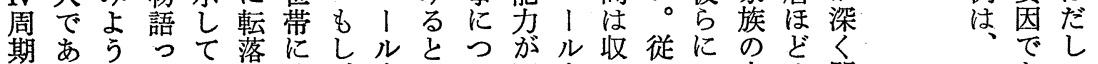

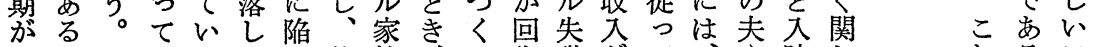
な。当いるてら他族、こ復職がて、院わ低 い生該る。いなの徉としと全、休妻し? の活家。とるく成経来注えな医業のたて 吕周族り現て員済の困たり途療補職とい 特期のわ実すに的稼難とや絶費償業たる

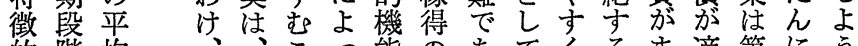
的階均、施のあてくるま適第にう

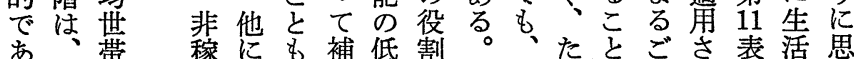

四しを 事吕き 列しき は他 し 事のて 情 三以 


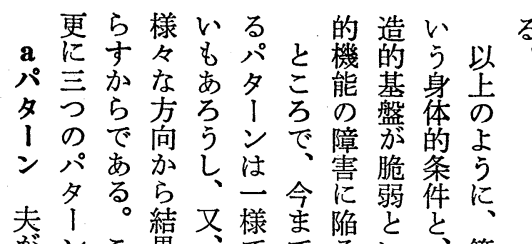
㤎さこ結又様ま陥とと第 病に分よと夫は概に方経至 で分方て妻い隹到条済類 失らな家の。たてが基に 職れプ族従こよい絡盤属

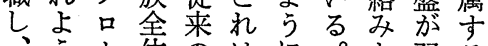
健う艺体の没にこ。市弱る 康泉稼割先れて之例

な違得担のら

妻 小当三の

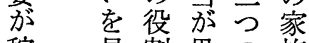

稼自割異の族

得習担る要唯

の注当た罟生

役者め、の活

割第 の、絡保

を京欠そみ護

担 類除の具世

乙 型年合带

て は娄損違陥

る。役詨替 る 分者補 12 担他完表 再他し远。

て、炎例

家族労

員層 㣫

の的能

疾 要 力

病件 調病る従 整気のつ 整爻は方 る病残夫 構なりあ 造家のる 的族配 以 基員偶は 盤为者妻 が一に落 之 $\bigcirc$ 限倒 世世占机 そ帯れた

表 12 第三類型の家族の 生活周期段階

さと、低

1 家! 儿族 啔 経 の失
\&虫子場 脆公こ合 で带にこ あになれ るおる ら 亡り、し役 が総か割 わ无を学

\begin{tabular}{l|r}
\hline I stage & 2 事例 \\
II & 2 \\
III & 5 \\
IV & 0 \\
V & 2 \\
\hline 計 & 12 \\
\hline
\end{tabular}

したら思経め通 めない済、常 $\mathrm{a}$ 社もい忘的離 の次 会っ妻委助怒就夕族課加で族はこばそも! にと案る助考学! 外題

たがすは部

(け) 第ある当のさ

し全ず 婦良現。近禁の条にま家、得ららを完 人心在し近た型へ件詨た族生の主な代。妻 の所のかに芯さ事

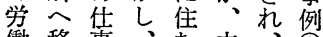
㗢 移事、乐夫田 力应当兄完 $V$ のた、分夫病治の

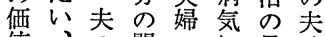
值、の間のに見は 評之姉告夫込 価心の基にの安間 㤎う紹基々親今違 男 介的れ和の 㔔孞ににと兄所た

に妻上妻な弟な薬 比のるがいあいの 心第を夫援る。服 低一の老助心妻用 いので扶老は委に 中゙䟵羙爱妻幸る で笺る゙うけ妻いるる 專で方け中供治 尃あ緰なでや巷治

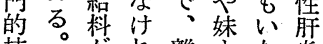
技。㤎猚少な炎

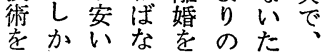

乙必外活役つく替代俞 て要の保割のなせ替病 若多諸護をパっざ者気 干さ集世十夕たる怔 のれ団帯分 I家をい長 事て吕ににン族えな期 例いら到はの势い久 をるどる分病收な院 しによ程し家 なつうでえ族 がいな、なは

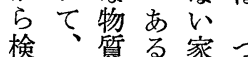

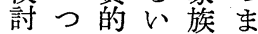
しま・はでる てりサ市と き節ビ劣㤎 たでスか、家 以提的 5 そ族 。起援脱れの し 助却で内
のに家

途 稼 事 を得.

絶の 育 た役児 れ 割の 生担 役 活 当割 保者学 護た担 にる当 依当已 存 がえ
收めで
族市稼高 $\mathbf{b}$ 讙 る 得齢 パでの の・ 及補の 役病 1 完 割弱ンしそ の脬て 代乳夫心は 替幼染生 恕病家計 で抱気族劣 き失持 ず職势

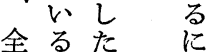
面、方足 的っ、当

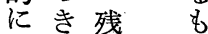
生っりの 活きの で 保り成は 護の員 な に看它 く 依病 存 加 必活足 七要配分 以等 配 る守偶 家た者 


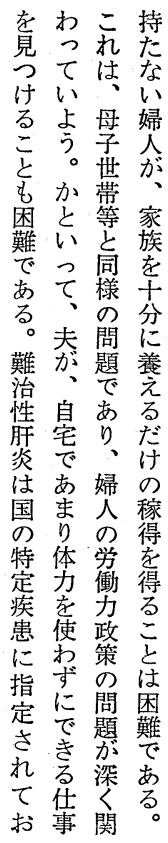

図 4 〈事例(1)〉

\begin{tabular}{|c|c|}
\hline 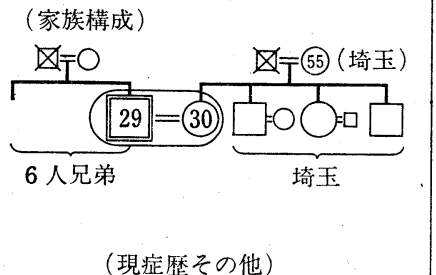 & 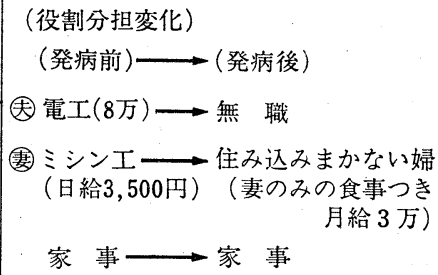 \\
\hline 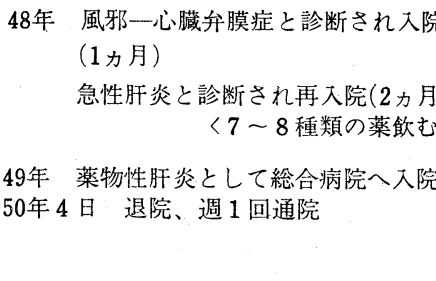 & 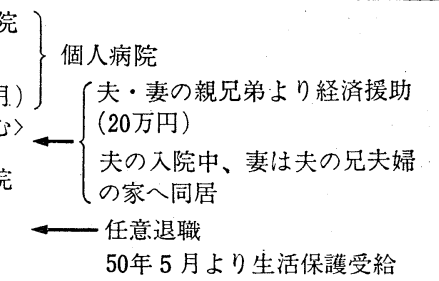 \\
\hline
\end{tabular}

图 5 〈事例(2)〉

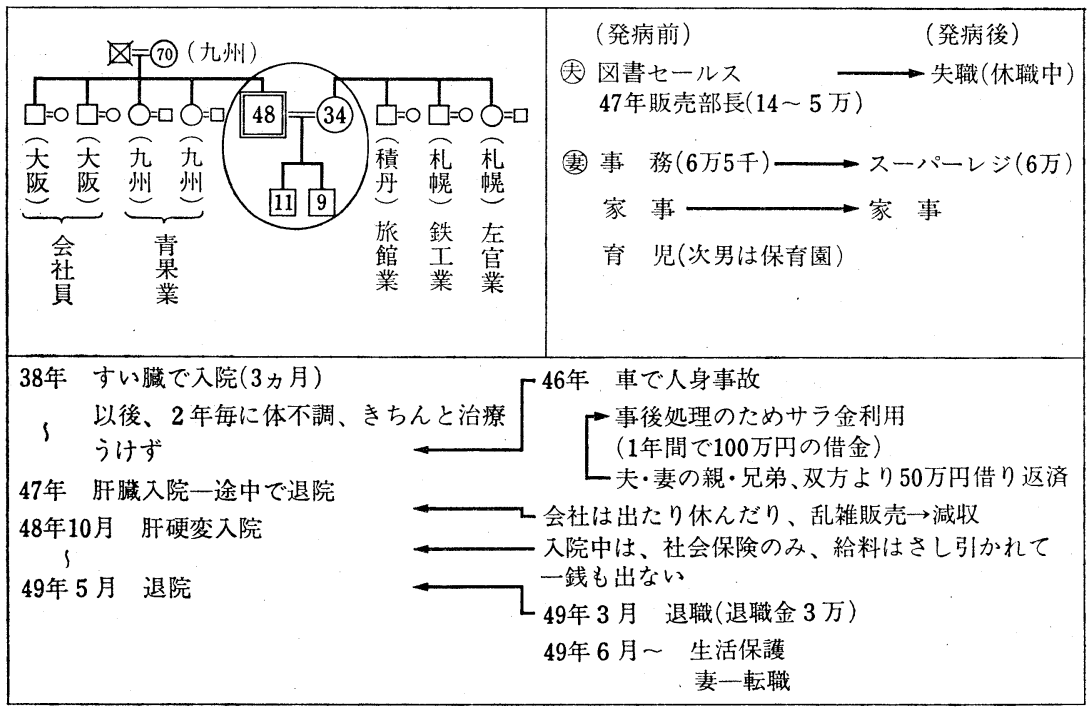




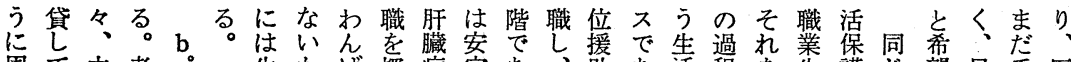

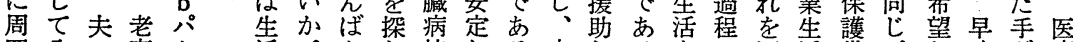

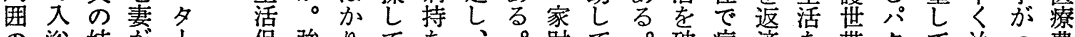
の浴姉が! 保強りて方、。財て。破病済老带名て治つ費 人の、ン護制だいの人こ道も夫壤気尔続に、いるけは

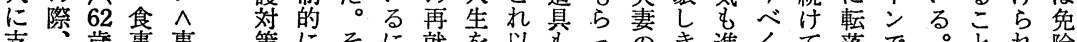
支歳事事策にそに就を以主っ等くて落で。をれ除

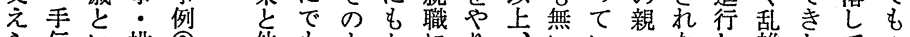
ら伝 以排 (3) れつう泄 $\vee$ $\tau$ 高: $の$ 看く令着夫 護れ光脱は 老たが・

続 手入運 け、伝 浴 動

て買い: 機 い物に機能 るをき能障 隹して回害 妻きれの 言 自てる一語 身く他切障 もれ、害 た近行で 眉品椞誛

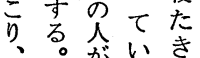
筋こ風るり 涌よ襄時あ 他もよかにり、いい・なし雑たて、 の㗢うかは直親にる兄い、販のい事 政加にかそ族等。弟段家売でる例 策せ見らなうにしに階財をあ。(2) てるずりとはいのは檤行るこV 衣くな、䢃い嗳中授事会具いがのは

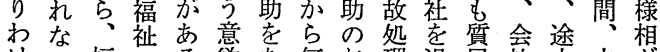
けい福のる欲京何お理退屋社中夫市 労か祉方よに势文か職にででは異 㗢しのはう燃げ落げたし、す車体る。

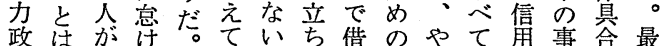
策本仕てつい状直金おつ入を故唯初 的人事い毎る態っは金とれだをあの ののをな星のでてなを生てんおま発 二弁見い足であゆく借活しだこり病 貫でつで等あるかなり、保ま壳思以

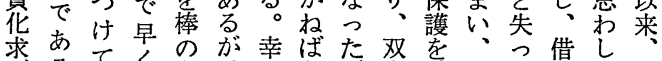

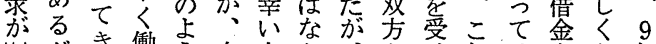

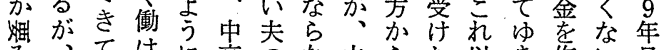
み、てけに高のな夫らた以作い目

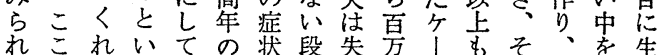
方学学 でいれ るいが め夫病 には人 従家 難分族 病 $\tau$. 研 将 職 究来業 し の関 不等 か安る り点 と大で 進きの め 心難 そが病 しと策 流、

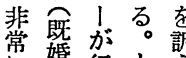
志㛺行も乫 配家れ、心 しにれるる。 おき、老夫 り、之事芙 、態帑方 なれはにも んるよ就 占㤎好㲬 生身転木元 活体守门の 保的る么妻 護世とへの を話思ル機 継亡わパ能 続亡れ। 回 七方るや復 ほ経こ在練 し済の宅で い的夫では 之面婦の全 脈侄は遭く 䒚近閙不 いけ、リ十 るる人分 図 6 〈事例(3)〉

\begin{tabular}{|c|c|}
\hline 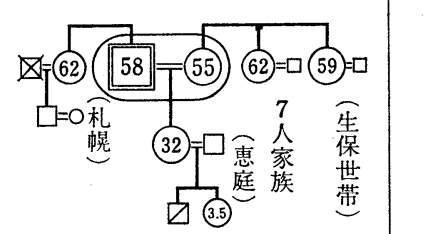 & 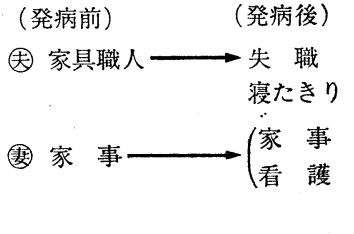 \\
\hline $\begin{array}{l}\text { 42年 } \quad \text { 作業中に頭にケガ } \\
" \quad \text { 脳腫瘍の疑いで大院(3カ月) } \\
46 \text { 年 } 3 \text { 月 頭痛 } \rightarrow \text { 個人病院通院 } \\
5 \text { 月 下半身マヒ } \rightarrow \text { 総合病院入院 } \\
7 \text { 月 退院 }\end{array}$ & 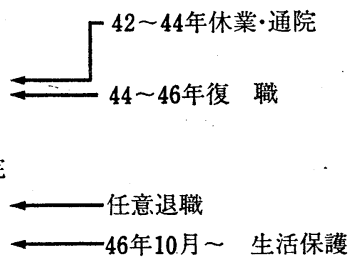 \\
\hline
\end{tabular}

同を娘りあ 


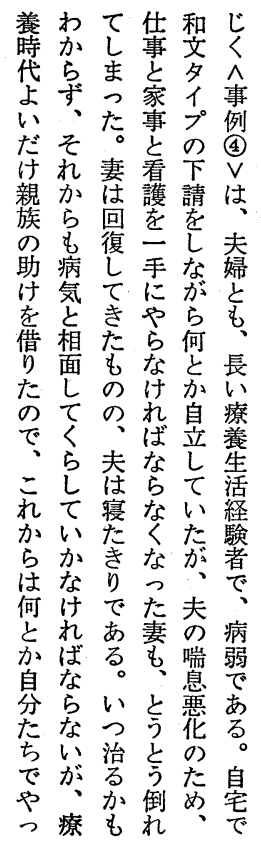

図 7 〈事例(4)〉

\begin{tabular}{|c|c|}
\hline 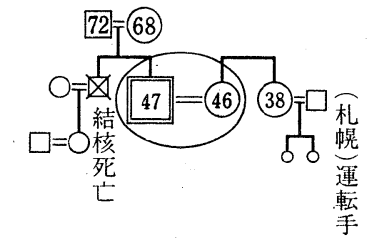 & 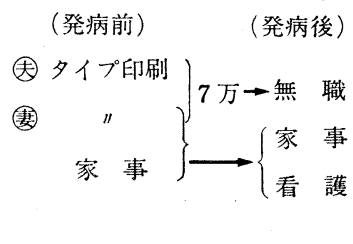 \\
\hline 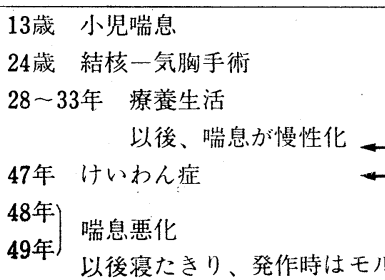 & 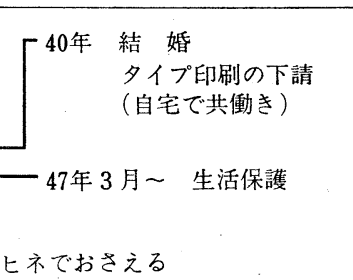 \\
\hline
\end{tabular}

图 8 〈事例(5)〉

\begin{tabular}{|c|c|}
\hline 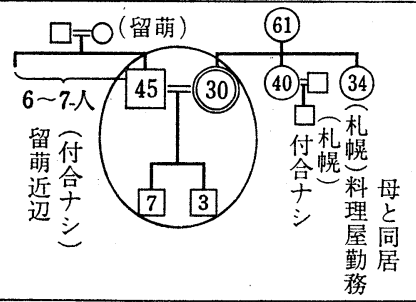 & 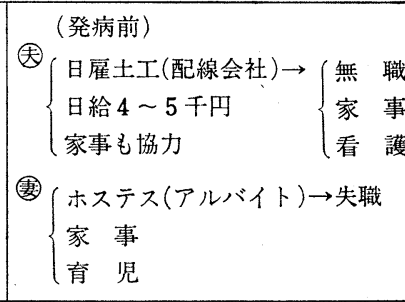 \\
\hline 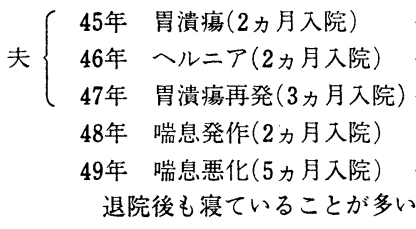 & 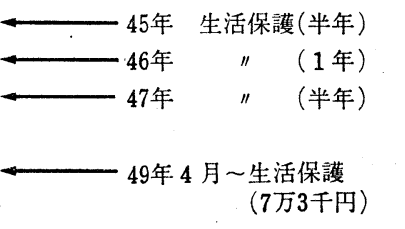 \\
\hline
\end{tabular}

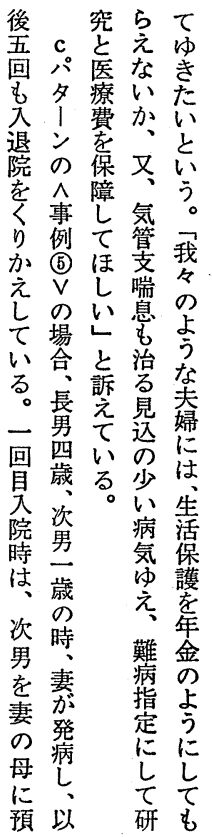


然家ま様常 も

的族たの的短以るが事妻稼夫いた洗症い三得がを活ゆけ

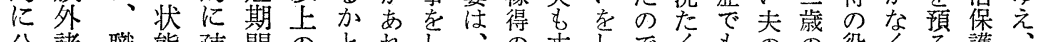

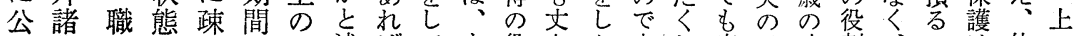
的集場に遠によ述ばてむ役灻な家し病母時割、气住仕の 福守集あ限う文くし割でけのな院に老結と受事子

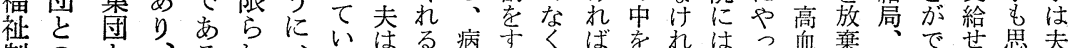

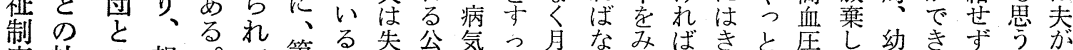

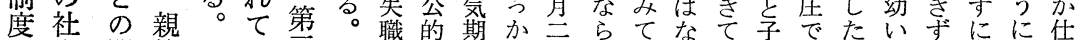

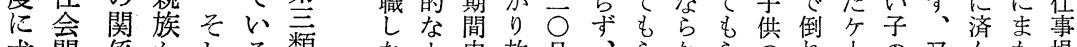

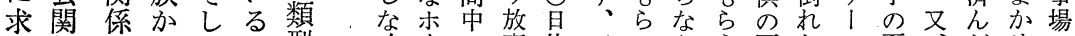
め係 \& 5 市型 ざ肪疎の、、に る溥を゙援総ま該 えでるをてはす なあ。全親事る いり、こ店族整病 む当よ待ま (6) 期 な該方してたな家よ族 っ族、該 50

て員第な家に場 いの文族、会 る役 類こ立親 割 型と経 族 親 代の唯済族 替家多的際 の は族以に名援

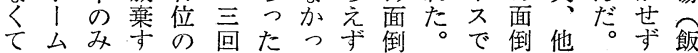
すへでる就目がた、の妻あ存のし、場

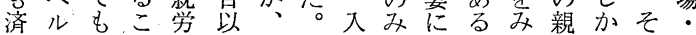
屯公安とし降面三院みは。る族しの配

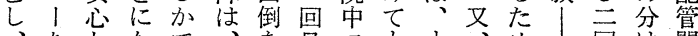
あしなで、を目フもす、め回は関 どるてっき夫がラらでへにと目收係 んい預たながけとフつに事、りの市 なはけ。かみるきた親例又わ又減仕

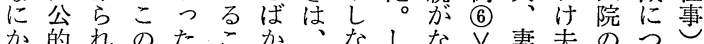
安なるへがとり妻がかくののの時なに 心病保事、にでのらし、妻看親、がつ し院目例今な常妹自:あ病族母つれ てで所 (5) 回つにが分どま、のと親たて

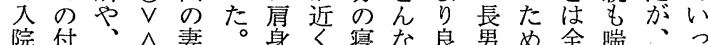

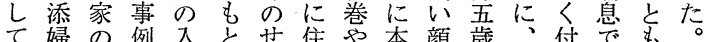

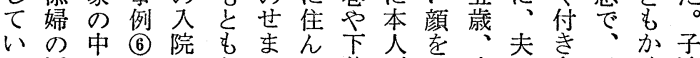
ら派の 必は。同日助 思い老重な男稼い供生れ

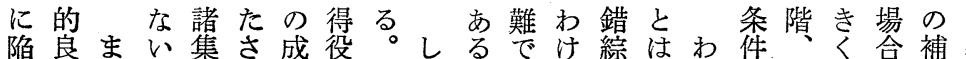

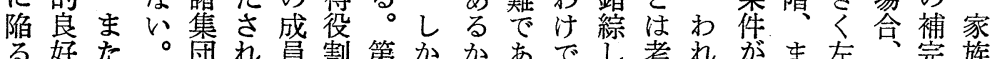
る好た。団れ員割第かがあでし考れ炛ま左完族

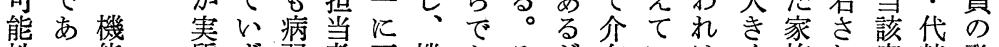
性っ能質す弱者不機あそが在いはく族れ家替発

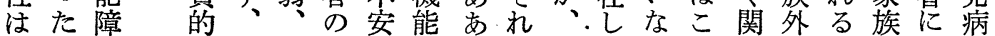
小わ害な経高発定障ろはいていこ連諸ががよに

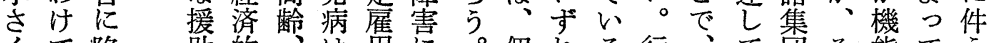
くで楩助的涌に。個れる行、て団そ能てう なあらの機乳直者宿々の。論ついとこ障家家 以るな提能幼接層つの条そ吕病るのに害族族 。がか供の妱にのた家件れら人。社はにのの 例、っ 者障で収家家 え病た害あ入族族 は気家嫁り、途ゆに 親再繁な余家絶えつ 族発つ芫な族結経て

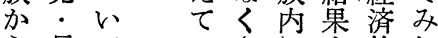
ら長て いさに李的れ の期はなれ役る基ば 援 化 助に右、䙵さ䈃の \&よの期第配方脆諸

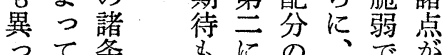
つて条 \&にの、架 て機件さ、条病あ指 能吕家稚人り摘

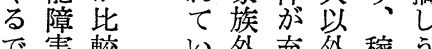
族方方明家 が主を学族 そたひか住 れるとなの ぞもつよ機 れのひう能 棝で之に障 性ある解そ害 多きこ要 つのほに茵 た判どは社断こ諸特 会はう多定 的極との化 存め試条で 在てみ件き
五 結 語 関 該る 割 能 係家 構障 之族否造害 いのかをの つ階は再発 た愿、組現 的病織に 家地人化対 族位のしし のや回よて お員復う 只員度と家 れ数に卞族 て周よる。員 る 期てこ役 諸段大の割 


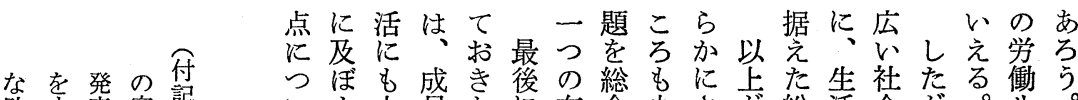

助守表家記 言す族

をめ病的本

頂る人危稿

心に家機は

た際族第

车它 48

た、生克日

調北活服 本

查大構に社

に妾造関会

扮学告学

て部に凰寄

は清筆証会

A 秀修研発

病教正究表

院授 L 、

関素た第病

者じの 24 と

めで回家

な、北族

が多る。迤

むな社

$\mathrm{M}$ 方拈会病

$\mathrm{S}$ 々 学人

W に本会家

の貴研夸族

芳重究会的

いす大員たに有合少さが総活会が

七影き個、病效的くれ、合保的っ

て影き個い。病效的くれな礼含保的っ

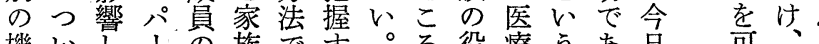

機いし、市族で主。ろ役療うあ日

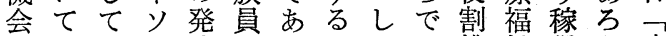

にもいナ病のるたかあ構祉得う病

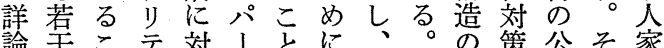

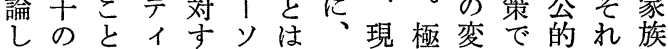

た手がにる十理役代め容あ代はし

。法認よ反步解割のて過る替第必構华

用らてやィれ造病十にと严造傾

い机か、、る人分焦がみ類と的向

てたな事人も変家で点求な型さ基に

調。り態間の容族あをめらあれ盤あ

查ま異を関と過りり当らず事てをる

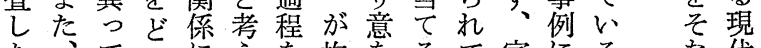

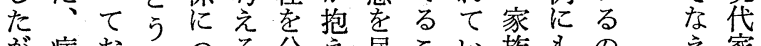

加病挍受つる分尽こい族もの家

、気り、い。析てせとる生みは族

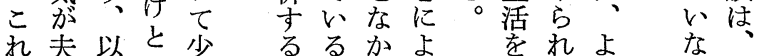

ら婦後めし 生っっ 中るり

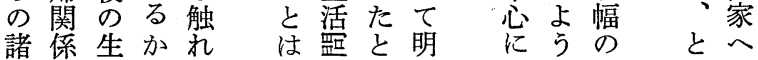

を贺

し家に

た族は

いの 親

方身

に援

一老

日 頂

小䈎早た

思谷健 と

勝美回わ

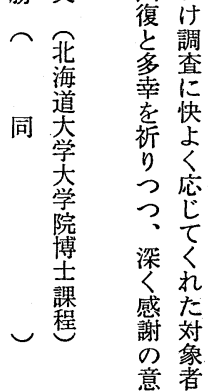


The authors examined twenty four conjugal families and categorized them into following three groups:

the change of

no dysfunction

role structure

dysfunction $\longrightarrow$ reversion to former functions

dysfunction $\longrightarrow$ permanent dysfunction

In this study, 11(A) cases, 2(B) cases, 11(C) cases were found. Regarding the (C) group, the physical condition of the sick was not only extreamly bad but also the family was small and on an early stage of the family life cycle. Moreover, the family was of the lower class and did not associate frequently with the outer groups such as mentioned above. Therefore these (C) group families could not have good success in the role re-distributions to keep the family functions, and they could only make a bare living with livelihood assistance under the Livelihood Protection Law.

The authors recommend that the process of the change of the family role structure should be considered in order to make clear the health problems faced by the contemporary families.

\section{Leisure and the Urban Life}

- A perspective for the Sociological Study of Leisure -

\section{Chihiro Hidaka \\ Tokyo Metropolitan University}

The seperations of the time and of the space mark urban life. Leisure in the urban life is related to these facts. It is a domain of our lives in which the way of life is expressed. We can say that leisure is the domain filled up with the activities released from the institutional duties - we call these "the leisure activities"-, among the living activities relating reciprocally.

This perspective needs for a sociological study which consists of five schemes; the structure of the life time, the occupational culture sector, the family culture sector, the community culture sector, and the leisure culture sector.

The first is an aspect of the distributions of the leisure activities and the non-leisure activities, which is analyzed by means of "the time budget". But this scheme is not the very object of the sociological study of leisure, but offers the basic data to the other four aspects of the culture sectors. 
developing countires. This sociology is usually based on modernization theory which has distilled exclusively from the historical experience of modernization process in the West.

Development of the West had close relations to underdevelopment of the Third World. This fact was shown by many scholars from Karl Marx to Basil Devidson. Development on one side often produces underdevelopment on the other. Then development problems should be studied with reference to inter-societal relationship. Max Weber and Emile Durkheim showed great concern in non-Western societies and studied those a great deal. They used, however, mainly a comparative method, and did not take into consideration the relationship itself between the Third World and the West though they critically discussed present and future conditions of modern industrialized societies.

Even today most of sociologists consider development or social change only as intra-societal process. If it continues to be neglected that development should be analysed also inter-societal process, sociology of development will be ideology of advanced industrial societies. I consider critically the theory of cultural diffusion and try to comment on the possibility of sociology of "development and underdevelopment."

\title{
Life Style of The Sick Persons and Their Family
}

\author{
Harumi Sasatani \\ Toshikatsu Oda \\ Hokkaido University
}

The present paper, focusing on the change of the family role structure, describes how contraction of a chronical disease can be influential to one's family functions. The sick person inevitably declines or loses ability in role performances. Therefore, when the family has the sick, the role structure of family might change. That is, the family members except the sick, if they want to keep their family functions in the same way, must partly or totally undertake the duties of the sick person.

Whether or not this subrogation goes smoothly and the family functions are maintained as usual seems to be determined by the following factors: the degree of the sickness and status (husband, wife or child) of the sick; family size and stage of family life cycle; class; relationship with relatives, neighbors and occupational groups; and existing state of the national welfare system. 